\title{
Competition and Bank Opacity
}

\author{
Liangliang Jiang \\ Lingnan University, Hong Kong \\ Ross Levine \\ University of California, Berkeley \\ Chen Lin \\ University of Hong Kong
}

November 12, 2014

\begin{abstract}
Did regulatory reforms that lowered barriers to competition among U.S. banks increase or decrease the degree to which banks manage the information that they disclose to the public and regulators? We find that relaxing regulatory impediments to competition reduced discretionary loan loss provisioning and the frequency with which banks restate financial statements. The results suggest that competition reduces bank opacity, enhancing the ability of markets and regulators to monitor banks.
\end{abstract}

Key words: Earnings management; Financial accounting; Bank deregulation; Corporate Governance

JEL Classification: G21; G28; G34, G38

* Jiang: Department of Economics, Lingnan University, Hong Kong. Email: liangliangjiang@ln.edu.hk; Levine: Haas School of Business at University of California, Berkeley, Milken Institute, and NBER. Email: rosslevine@berkeley.edu. Lin: Faculty of Business and Economics, the University of Hong Kong, Hong Kong. Email: chenlin1@hku.hk. We thank Patricia Dechow, Yaniv Konchitchki, Xu Li, Chul Park, Yona Rubinstein, Richard Sloan, Feng Tian, Xin Wang and seminar participants at the Federal Reserve Bank at Saint Louis, University of California, Berkeley and University of Hong Kong for helpful comments and discussions. 


\section{Introduction}

When banks manipulate their financial statements, this can interfere with the monitoring, governance, and regulation of banks with harmful effects on the entire economy. Banks frequently manage financial statements to (a) circumvent capital requirements (Ahmed et al., 1999; Collins et al., 1995), (b) reduce taxes (Beatty and Liao, 2011), and (c) smooth earnings (Beatty et al., 2002; Liu and Ryan, 2006). Research also suggests that such manipulations can increase bank fragility (Bushman and Williams, 2012; Huizinga and Laeven, 2012; and Cohen et al., 2014) and reduce the quality of bank lending (Beatty and Liao, 2011). More generally, King and Levine (1993a,b), Jayaratne and Strahan (1996), and Beck et al (2000) suggest that any factor-including the manipulation of financial statements - that interferes with the sound oversight and governance of banks can distort capital allocation and slow economic growth.

Nonetheless, little is known about the impact of bank regulations on the extent to which banks manage their financial accounts. Although cross-country studies find that banks allocate capital more efficiently in countries that penalize bank executives for disclosing erroneous information (Barth et al., 2004, 2006, 2009; Beck et al., 2006), unobserved country characteristics might account for these results. Moreover, researchers have not examined an array of bank regulations that might also shape earnings management. As stressed by Beatty and Liao (2014), the lack of research on the regulatory determinants of financial disclosure in the banking industry is surprising given the importance of bank performance for economic prosperity, the deleterious effects of managing financial statements on bank performance, and the frequency with which banks manipulate their accounts.

In this paper, we provide the first assess of the impact of bank regulatory reforms that lowered barriers to competition among U.S. banks on the degree to which banks manage the information that they disclose to the public and regulators. Theory offers conflicting perspectives on the impact of competition on the quality of financial statements. Scharfstein (1988), Darrough and Stoughton (1990), and Wagenhofer (1990) argue that competition can induce incumbent firms to manipulate the release of information to hinder the entry of rivals. Shleifer (2004) maintains that greater competition spurs executives to engage in less ethical 
behavior, including more aggressive accounting practices. Stein (1989), von Thadden (1995), and Kedia and Philippon (2009) show that competition can spur executives to manage their accounts to extract short-term rents. In contrast, other models stress that competition enhances the governance of firms, potentially compelling managers to disclose more reliable information to investors, e.g., Hart (1983), Schmidt (1997) and Shleifer and Vishny (1997). Furthermore, since cross-firm comparisons help investors detect and deter earnings management (Dichev et al., 2013), product market competition that facilitates such comparisons will enhance corporate transparency (Holmstrom, 1982).

To evaluate these differing views on the impact of competition on quality of information disclosed by banks, we exploit three sources of variation in the cross-state, cross-time removal of regulatory impediments to bank competition during the last quarter of the $20^{\text {th }}$ century. First, individual states eliminated restrictions on intrastate branching. In particular, for much of the twentieth century, most states limited the ability of banks to compete with each other by imposing regulatory restrictions on banks establishing branch networks within states. States removed these barriers to competition in different years. Second, interstate bank reforms eased regulatory impediments to competition, as bank holding companies (BHCs) headquartered in one state could now compete in other states by establishing subsidiaries in those states. As emphasized by Goetz et al. (2013), not only did states begin interstate deregulation in different years, these reforms progressed in a state-specific process of bilateral and multilateral agreements. Thus, we use several time-varying measures of the degree to which a state's banking market was exposed to competition from BHCs in other states. Third, while the Riegle-Neal Act of 1995 effectively eliminated both intrastate branch and interstate bank restrictions, states had leeway in the timing of interstate branch deregulation, which is when BHCs in one state can establish branches - not just separately capitalized subsidiaries - in other states. Since the costs of establishing a branch are lower than the costs of establishing a subsidiary, interstate branch deregulation further lowered barriers to competition. Considerable research indicates these regulatory reforms spurred competition among banks (Jayaratne and Strahan, 1998; Stiroh and Strahan, 2003; Johnson and Rice, 2008). 
We use two types of proxies of disclosure quality. First, we use several measures of discretionary loan loss provisions (LLPs). LLPs are the most important bank accrual through which banks manage earnings and regulatory capital (Beatty and Liao, 2014). ${ }^{1}$ To construct a proxy of discretionary LLPs (Dechow et al., 2010), we first obtain the residuals from a model of the accruals of LLPs. Beatty and Liao (2014) assess alternative models and find that the residuals from one are particularly effective at predicting earning restatements and comment letters from the Securities and Exchange Commission (SEC). We estimate a similar form of this model, collect the residuals, and compute the logarithm of the absolute value of the residuals as our measure of discretionary LLPs, i.e., of "abnormal" accruals of LLPs. Since both positive and negative residuals may signal manipulation of LLPs, we use the absolute value of the residuals. Moreover, we show that the results are robust to using several alternative empirical models of LLPs, including some proposed by the literature on disclosure quality and some that we developed to address concerns with standard models of LLPs. The second type of proxy of disclosure quality is the frequency with which banks restate their earnings. Financial restatements have the advantage of measuring the actual correction of financial accounts, rather than estimating discretionary LLP by a regression residual. However, since data on restatements are limited, we use both proxies for disclosure quality.

We employ a difference-in-differences estimation strategy to assess the impact of bank regulatory reforms that removed barriers to competition on the degree to which BHCs' discretionary LLPs may change. The dependent variable is a measure of discretionary LLPs for each $\mathrm{BHC}$ in each period (or a measure of financial restatements). The core independent variables are measures of intrastate branch, interstate bank, and interstate branch deregulation, which vary by state and year, and in some specifications vary by BHC-year. The analyses condition on BHC and year-quarter fixed effects and control for an array of time-varying BHC traits. Given data availability, we conduct the analyses over the period from 1986 through 2006 using quarterly data.

\footnotetext{
${ }^{1}$ Provision for loan losses is an expense on a bank's income statement. Allowances for loan losses enter as an asset on the bank's balance sheet, where these allowances equal the accumulated loan loss provisions from income statements minus write offs from recognized losses on loans.
} 
There are good reasons for treating the bank regulatory reforms as exogenous to discretionary LLPs. Kroszner and Strahan (1999) show that the timing of bank deregulation reflects the interaction between technology shocks at the national level and pre-existing conditions at the state level. Furthermore, several studies show that the timing of deregulation does not reflect bank performance (Jayaratne and Strahan, 1998; Goetz et al., 2013) or state economic performance (Jayaratne and Strahan, 1996; Morgan et al., 2004; Demyanyk et al., 2007; Beck et al., 2010). Moreover, we demonstrate below that discretionary LLPs do not predict the timing of bank deregulation and there are no trends in LLPs prior to deregulation.

Our initial assessments suggest that regulatory reforms that lowered barriers to bank competition reduced discretionary LLPs. For each of the three different types of regulatory reforms, we find a negative, statistically significant, and economically large impact on discretionary LLPs. For example, consider the traditional measure of the timing of interstate bank deregulation as the year when a state first deregulated with any other state. We find that after this event, discretionary LLPs are half as large as they were before deregulation. As another example, consider our state-specific, time-varying measure of the process interstate bank deregulation. That is, for each state $j$ in each year $t$, we measure the number of other states with which it has interstate banking agreements. We also consider variants of this deregulation measure that weights other states by their distance to state $j$ and by the economic sizes of those other states. Our estimates indicate, for example, that when a state eliminates interstate banking restrictions with ten other states, discretionary LLPs fall by about $10 \%$. We confirm these findings when examining financial restatements. There is a negative relationship between regulatory reforms that lowered barriers to competition and the frequency of financial restatements with the SEC.

These findings, however, are subject to a potentially important concern: Perhaps bank deregulation influences the quality of bank financial statements through some other mechanism besides an intensification of competition. Perhaps, when states lowered barriers to the entry of banks from other states, this triggered other changes that reduced disclosure quality. Even though the intrastate branch, interstate bank, and interstate branch deregulations were specifically designed to lower barriers to the contestability of banking markets and even 
though past research finds that these reforms intensified competition (Jayaratne and Strahan, 1998; Stiroh and Strahan, 2003; and Johnson and Rice, 2008), this does not necessarily mean that deregulation boosted disclosure quality by intensifying competition.

Consequently, we offer a new approach for more precisely identifying the impact of competition on bank behavior that builds on Goetz et al. $(2013,2014)$. The approach is based on the "gravity model" assumption that distance matters for investment and hence for the degree of competition faced by different BHCs in the same state. For example, after state $j$ allows BHCs in state $i$ to enter and establish subsidiaries in state $j$, two subsidiaries in state $j$ may face different competitive pressures from state $i$, depending on their distance to state $i$. More concretely, when California deregulates with Arizona, the banks in southern California may face greater competitive pressures from BHCs in Arizona than banks in northern California. By integrating this gravity model into the process of interstate bank deregulation, we build a time-varying, BHC-specific measure of regulatory-induced competition.

Specifically, we first construct measures of the competitive environment facing each subsidiary. For each subsidiary in each period, we identify those states whose BHCs can enter the subsidiary's state. We then weight each of those states by the inverse of its distance to the subsidiary. Second, after computing this inverse-distance measure of competition for all subsidiaries and time periods, we calculate the competitive environment facing a consolidated BHC by weighting these subsidiary level measures of competition by the proportion of each subsidiary's assets in the aggregate BHC. This approach also accounts for the fact that a BHC's competitive-environment will change as the states in which it has subsidiaries change their policies, which has not been previously addressed. For example, a BHC headquartered in state $i$ with subsidiaries in other states will experience changes in competition as those other states deregulate, subjecting the BHC to greater competition even if state $i$ does not open-up further to other states. In computing these BHC-specific-time competition measures based on regulations and distance, we also calculate and examine other measures that incorporate information on the economic sizes of different states.

Armed with these BHC-specific-time measures, we then re-do the analyses of the regulatory determinants of banks' abnormal accruals of LLPs while simultaneously including 
the original state-time indicators of interstate banking reforms and these BHC-specific-time measures of the competitive environment facing each BHC. If the earlier results were driven by a change in some state-time factor occurring when two states lower barriers to interstate banking, then the BHC-specific-time measure of competition should not provide additional explanatory power in the discretionary LLP analyses. If, however, increases in competition account for the earlier findings (and distance influences the contestability of markets), then we should find that these BHC-specific-time measures of competition influence discretionary LLPs beyond the state-time measures of interstate bank deregulation.

The BHC-specific-time measures of the regulatory-induced competitive pressures facing each BHC are strongly and negatively associated with discretionary LLPs even when including the original state-time measures discussed above. The findings are not driven by changes in regulation, supervision, or other policies at the state level. These findings further emphasize that interstate bank deregulation reduced discretionary LLPs.

Our work also contributes to the active debate on the impact of competition on literature on competition and corporate disclosure quality that has focused on nonfinancial firms. Ali et al., (2009) and Berger (2011) stress that challenge to finding sound proxies for competition and exogenous sources of variation in competition have helped yield inconclusive results on competition and corporate disclosure. Furthermore, while much of this literature uses cross-industry comparisons to assess the impact of competition on disclosure quality, other cross-industry differences make it difficult to draw causal inferences. In contrast, we focus on one industry and offer a new strategy for assessing the impact of competition-enhancing reforms on banks' abnormal accruals of LLPs.

The paper proceeds as follows. Section 2 discusses the data and empirical methods. Section 3 presents the main results. Section 4 discusses robustness tests. Section 5 concludes. 


\section{Data, Methodology, and the Validity of the Identification Strategy}

\subsection{Data on BHCs and states}

The Federal Reserve provides consolidated balance sheets and income statements for BHCs on a quarterly basis starting in June 1986. We examine the ultimate parent BHC that owns, but is not owned by, other banking institutions, where we define ownership as $50 \%$ or more of the financial institutions equity. More specifically, we follow Goetz et al. (2013) and use code RSSD9364 in the Y-9C reports to link bank subsidiaries to the parent BHCs and code RSSD9364 to assign a subsidiary bank to the parent BHC if the latter owns at least 50\% of the subsidiary's equity stake. In robustness tests, we examine individual commercial banks, rather than parent BHCs, using data from the Reports of Condition and Income ("Call Reports"), and obtain qualitatively similar results. We focus on the parent BHC results both because many commercial banks are not public listed and hence do not have stock price data and because diversification during our sample period occurred primarily through BHC subsidiaries, not through the branch networks of commercial banks.

Our sample contains 27,137 BHC-quarter observations on 911 BHCs headquartered in one of 48 states or the District of Columbia. Consistent with the literature on US bank deregulation, we exclude the states of Delaware and South Dakota from our sample because they changed their laws to encourage the entry and formation of credit card banks.

For stock prices, financial restatements, and state characteristics, we use several additional datasets. Center of Research in Security Prices (CRSP) has information on stock prices and outstanding shares. We construct a dataset on financial restatement information manually from 10-K, 10Q, and 8-K files from EDGAR, which gathers information from the Securities and Exchange Commission (SEC) filings of public firms. The Bureau of Economic Analysis provides state-level data on social and economic demographics. 


\subsection{The dates of bank deregulation}

We use the timing of three types of bank deregulation as exogenous sources of variation in the competitiveness of the banking market in each U.S. state. During the last quarter of the twentieth century, federal and state authorities reduced restrictions on (1) intrastate bank branching - the ability of banks to establish branches within a state, (2) interstate banking - the ability of banks to establish subsidiary banks across states, and (3) interstate branching - the ability of banks to establish branches across states. These policy changes increased the contestability of banking markets, as a broader array of banks within a state and from different states could compete to sell banking services. Reflecting this competition, deregulation reduced interest rates on loans, increased interest rates on deposits, and did so without boosting loan delinquency rates (Jayaratne and Strahan, 1996, 1998). Johnson and Rice (2008) summarize the history of U.S. deregulation of geographic restrictions on banking.

With respect to intrastate bank branching, most states restricted branching within (and across) state borders for much of the $20^{\text {th }}$ century. From the mid-1970s through the mid-1990s, states relaxed regulatory restrictions on the ability of BHCs to form branch networks within state. This relaxation evolved gradually, with the last states lifting restrictions following the 1994 passage of the Riegle-Neal Interstate Banking and Branching Efficiency Act. Consistent with Jayaratne and Strahan (1996) and others, we choose the date of intrastate branch deregulation as the date on which a state first permitted banks to establish branch networks. Thus, INTRA equals one for BHCs headquartered in a state in the periods after that state initiates intrastate branch deregulation and zero otherwise. To be compatible with the quarterly level BHC-characteristic data, we assume that the deregulation happens in the last quarter of the year in which the state deregulated, so that INTRA equals one starting from the first quarter of next year. We also make similar assumptions for the other deregulation dummy variables.

States also engaged in a process of interstate bank deregulation, in which a state allowed banks from other states to acquire or establish subsidiary banks in its borders. Over the period from 1978 through 1994, states removed restrictions on interstate banking in a 
dynamic, state-specific process either by unilaterally opening their state borders and allowing out-of-state banks to enter or by signing reciprocal bilateral and multilateral agreements with other states. The process of interstate bank deregulation ended with the passage of the Riegle-Neal Act of 1994 that eliminated restrictions on BHCs establishing subsidiary bank networks across state boundaries.

There are several ways to date interstate bank deregulation. Most researchers simply define a state as "deregulated" after it first lowers barriers to interstate banking with at least one other state. In our analyses, INTER equals one for BHCs headquartered in a state in the years after that state first allows interstate banking and zero otherwise.

More recently, Goetz et al. (2013) exploit the dynamic process of each state's removal of impediments to out-of-state banks to date interstate bank deregulation. Based on this work, we construct three measures of interstate bank deregulation. Ln(\# of States) ${ }_{j t}$ equals the natural logarithm of one plus the number of states whose banks can enter state $j$ in year $t$. This measure evolves in a state-specific manner as some states unilaterally open their borders and others proceed with a process of bilateral and multilateral reciprocal arrangements. $\operatorname{Ln}(\#$ of States-Distance Weighted) $)_{j t}$ equals the natural logarithm of one plus the number of other states whose banks can enter state $j$ in year $t$, where each of these other states is weighted by the inverse of their distance from the state. We construct and use Ln(\# of States-Distance Weighted $)_{j t}$ because BHCs might find it more beneficial and less costly to enter close states rather than distant ones, with corresponding ramifications on the competitiveness of banking markets. The third measure is $\operatorname{Ln}(\# \text { of BHCs from Other States })_{j t}$, and it equals the natural logarithm of one plus the number of BHCs in states that can enter state $j$ in year $t$. This measure allows for the possibility that a state's BHCs will face more competition when there is an increase in the number of BHCs from other states that can enter its market.

States also relaxed restrictions on interstate bank branching. While the Riegle-Neal Act of 1994 effectively removed restrictions on interstate banking, it allowed states some discretion on the timing of the lowering of barriers to the establishment of branch networks by BHCs in other states. So, BHCs from state A were able to establish a subsidiary in state B after 1994, but they were not necessarily able to establish branches in state B. The year in 
which states allowed interstate branching varies between 1994 and 1997. In the analyses below, INTER-BRANCH equals one if a $\mathrm{BHC}$ is headquartered in a state that allows the BHCs from other states to establish branch networks and zero otherwise. Appendix Table 1 provides the dates of INTRA, INTER, and INTER-BRANCH for each state.

\subsection{Estimating Discretionary Loan Loss Provisions}

Loan loss provisions (LLPs) are a major, if not the major, mechanism through which banks manage both earnings and regulatory capital. There is not a consensus strategy or measure of the degree to which banks manipulate the information that they disclose to the public and regulators by managing their financial statements. One approach is to examine the frequency with which banks restate their financial statements and we examine this below. A second approach is to estimate a model of LLPs and use the absolute values of the residuals to construct indicators of the "abnormal" accrual of LLPs, i.e., as discretionary LLPs. This approach relies on estimating a sound model of LLPs. Beatty and Liao (2014) assess nine different LLP proposed by the banking literature. They find that one model performs particularly well in predicting earning restatements and comment letters from the Securities and Exchange Commission. We use a similar form of this model in our core analyses and then show that the results are robust to using alternative models LLPs to construct proxies of discretionary LLPs.

We construct discretionary LLPs for each BHC in each period using the following two-step procedure. We first run the core regression model highlighted by Beatty and Liao (2014) to separate the systemic component of LLPs, i.e., the component of LLPs accounted for by fundamental BHC and state determinants, from that part of LLPs unaccounted for by these fundamental determinants. To account for the impact of deregulation on the level of LLPs, we also additionally include deregulation measures. The results are robust to excluding the deregulation measures and to simply using the Beatty and Liao (2014) models, as reported in the Appendix tables. Moreover, as we discuss below, the results hold when we include all of the explanatory variables that we use to evaluate the determinants of discretionary LLPs in the equation for LLPs. 
Specifically, we run the following regression:

$$
\begin{gathered}
L L P_{i j t}=\alpha_{0}+\alpha_{1} d N P A_{i, j, t+1}+\alpha_{2} d N P A_{i j t}+\alpha_{3} d N P A_{i, j, t-1}+\alpha_{4} S I Z E_{i, j, t-1}+ \\
\alpha_{5} d L O A N_{i j t}+\alpha_{6} \operatorname{CSRET}_{j t}+\alpha_{7} d G S P_{j t}+\alpha_{8} d U N E M P_{j t}+\alpha_{9} S T_{j}+\alpha_{10} D_{j t}+\varepsilon_{i j t}
\end{gathered}
$$

In this model, $D_{j t}$ represents the bank deregulation measures that we define above. $d N P A_{i j t}$ represents the change in non-performing assets between quarter $t$ and $t-1$ divided by total loans in quarter $t-1$ for BHC $i$ in state $j$. Following Bushman and Williams (2012), this model includes current period $d N P A_{i j t}$ and next period $d N P A_{i, j, t+1}$ because banks might use current and forward-looking information on non-performing assets in selecting LLPs. The model includes $d N P A_{i, j, t-1}$ since banks might use historical changes in non-performing assets in setting LLPs. ${ }^{2} S_{Z Z E_{i, j, t-1}}$ is the natural logarithm of total assets in quarter $t-1$ and is included because official supervisory oversight and private sector monitoring might vary with banks size. $d L O A N_{i j t}$ is the change in total loans over the quarter divided by lagged total loans. This is included to allow for the possibility that an increase in loans is associated with a decrease in loan quality. The model also includes three measures state characteristics that might influence LLP: $C S R E T_{j t}, d G S P_{j t}$, and $d U N E M P_{j t}$ represent the return on the Case-Shiller Real Estate Index, the change in GSP, and the change in the state's unemployment rate, respectively. We also include state fixed effects, $S T_{j}$, to account for any time invariant state characteristics that shape loan loss provisioning.

In the second step, we construct a proxy for the discretionary LLPs of each BHC in each quarter as the logarithm of the absolute values of the errors from estimating equation (1). The errors represent the "abnormal" accrual of LLPs - the component of LLPs unexplained by the regression's fundamental determinants. We use the absolute value of the residuals because both positive and negative residuals may reflect discretionary manipulation of LLPs above and beyond that accounted for by the regressors in equation (1). An extensive literature uses errors from such models to proxy for earnings management (e.g., Beatty and Liao, 2014;

\footnotetext{
${ }^{2}$ We do not include the two period lag of $d N P A$ as in Beatty and Liao (2014) mainly because of the concern on losing too many observations. However, including the two period lag of $d N P A$ does not affect the results.
} 
Dechow et al., 1995, 2006, 2010; Yu, 2008; Jiang et al., 2010). We interpret the results reported below under the maintained hypothesis that this proxy reflects the discretionary management of LLPs. As a robustness check, we also conduct the analyses by first averaging the residuals from the quarterly frequency to an annual frequency before taking the logarithm of the absolute value of the residuals and find the results highly robust. For brevity, the results are not presented but are available on request. Table 1 provides definitions of the variables used in the paper.

Table 2 reports summary statistics for the sample obtained after dropping observations in which the core explanatory variables have missing values. In our sample, the median $\mathrm{BHC}$ has $\$ 1.1$ billion in total assets $(S I Z E)$, while the average value of SIZE is $\$ 11.0$ billion. Given the skewed distribution of bank size, we take the logarithm of total assets $(\log S I Z E)$ in the regression analyses. Table 2 also shows that both the mean and the median of non-performing assets $(N P A)$ in our sample is $\$ 10,000$ per quarter. The median and mean of total loans $(L O A N)$ ) are $\$ 680$ million and $\$ 5,880$ million, respectively. In terms of the change in total loans scaled by beginning total loans $(d L O A N)$, the mean and median are 0.03 and 0.02, respectively, which are much less skewed than $L O A N$.

\subsection{Empirical Methodology}

We examine the relationship between discretionary LLPs by BHCs and bank deregulation using a difference-in-differences methodology. This strategy allows us to control for all time-invariant BHC and state characteristics as well as all time effects. Furthermore, we condition on a wide array of time-varying BHC characteristics. Our difference-in-differences methodology employs quarterly data on BHCs, and we confirm the findings when aggregating to an annual frequency. Thus, we evaluate the effect of deregulation on earnings management by estimating the following model:

$$
\text { Discretionary } L L P_{i j t}=\alpha_{t}+\alpha_{i}+\beta^{\prime} \cdot D_{j t}+\gamma^{\prime} \cdot X_{i j t}+\varepsilon_{i j t} \text {, }
$$


where Discretionary $L L P_{i j t}$ is the measure of the manipulation of loan loss provisions by BHC $i$, headquartered in state $j$, in quarter $t$, and equals the logarithm of the absolute value of the residuals from equation (1). $D_{j t}$ is bank deregulation in state $j$ and in quarter $t$. For bank deregulation, we use the measures of intrastate, interstate bank, and interstate branch deregulation defined above. To emphasize, the deregulation measures used in each version of equation (2), are also used in the equation (1) estimation of LLPs. We also include year-quarter fixed effects $\left(\alpha_{t}\right)$ and BHC fixed effects $\left(\alpha_{i}\right)$, and a vector $X_{i j t}$ of time-varying BHC traits that might explain the management of LLPs. Specifically, following the literature on the quality of banks earnings statements (Beatty et al., 1995, 2002; Liu and Ryan, 2006; Kanagaretnam et al., 2010), $X_{i j t}$ includes the logarithm of bank assets (logSIZE), one year lag of loan loss provision scaled by beginning total loans (LLP_lag), negative net income indicator variable (LOSS), and bank capital ratio $(C A P)$. The results hold when including all of these $X_{i j t}$ variables in the equation (1) model for LLPs. In robustness tests, we control for earnings before tax and provisions $(E B T P)$ and obtain the same results, e.g., no difference in the statistical significance of or appreciable difference in the estimated coefficient on bank deregulation. We provide the estimates without EBTP since competition may influence discretionary LLPs through its effect on earnings. Similarly, the results are robust to controlling for the particular features of each BHC's loan portfolio, such as the proportion of real estate, commercial and industrial, agriculture, individual, and foreign loans. Including these loan types does not alter the findings.

\subsection{On the validity of our approach}

Drawing valid inferences from these regressions requires that the change in discretionary LLPs in deregulated and regulated states would have been the same in the absence of deregulation. If the trend in abnormal accruals of LLPs differed in deregulating non-deregulating states - if the treatment group had a different trend in outcomes from the control group, then our estimation strategy could yield erroneous inferences.

To assess the validity of our identification strategy, we conducted two types of analyses. First, we present graphs regarding the relationship between discretionary LLPs and 
the timing of interstate bank deregulation that illustrate (1) abnormal accruals of LLPs do not predict the timing of deregulation and (2) the reduction in abnormal accruals occurs immediately after a state started the process of interstate bank deregulation.

Figure 1 illustrates the evolution of discretionary LLPs before and after interstate bank deregulation. We start by making year zero the year when a state started interstate bank deregulation. Then, time for each state is centered at year zero, such that one quarter before deregulation is -1 and one quarter after deregulation is +1 . We then run the following regression:

Discretionary $L L P_{i t}=\alpha_{t}+\alpha_{i}+\beta_{1} D_{i t}^{-10}+\beta_{2} D_{i t}^{-9}+\cdots+\beta_{20} D_{i t}^{+10}+\varepsilon_{i t}$, where the deregulation dummy variable $D_{i t}^{+n}$ equals one for banks in the $n$th quarter after deregulation, and the deregulation dummy variable $D_{i t}^{-n}$ equals one for banks in the $n$th quarter before deregulation, and $\alpha_{t}$ and $\alpha_{i}$ are state-quarter and BHC fixed effects, respectively. We consider a 20-quarter window, spanning from ten quarters before until ten quarters after deregulation. We then plot the estimated coefficients on the deregulation dummies and provide $5 \%$ confidence intervals.

Figure 1 indicates that there is a distinct break in the time-series of abnormal accruals of LLPs when states start interstate bank deregulation. ${ }^{3}$ There is no evidence of trends in discretionary LLPs before interstate bank deregulation. While this figures does not control for time-varying state and BHC specific information, the sharp break in discretionary LLPs is consistent with deregulation changing discretionary LLPs.

Furthermore, we plot the trend of the median value of discretionary LLPs scaled by EBTP $(D-L L P / E B T P)$ of each BHC in a state during the period of interstate deregulation, where EBTP equals income before taxes and provisions in million U.S. dollars. The discretionary LLPs is the absolute value of discretionary LLPs estimated from equation (1) multiplied by the value of the lag of total loans, which is also measured in million U.S. dollars. Similarly, we still consider a 20-quarter window, spanning from ten quarters before

\footnotetext{
${ }^{3}$ Our sample shows that the majority of states established out-of-state subsidiaries in the first year that the deregulation was implemented, which is consistent with our finding that the reform impact on discretionary LLPs is immediate.
} 
until ten quarters after deregulation. The median EBTP of our sample BHCs is $\$ 3.02$ million, and the median of discretionary LLPs is $\$ 0.43$ million. In Figure 2, we find similar trend for the $D-L L P / E B T P$ that it has large fluctuations during the pre-deregulation period, with the mean ratio around $30 \%$. In contrast, during the post-deregulation period, this ratio quickly reduced to about $13 \%$, and became much more stable than before. In the meantime, we do not find statistical significant increases in EBTP during the post deregulation period. This is because there is no increase in the overall credit demand, and the reduced costs in banking after deregulation have been passed along to bank customers in the form of lower loan rates (Jayaratne and Strahan, 1996; Rice and Strahan, 2010). This result not only reinforces the findings from Figure 1 that there is a statistically significant drop in abnormal LLPs after interstate deregulation, but also shows that this drop is economically large relative to a BHC's earnings.

For the second type of test of the validity of our approach, we tested whether LLPs in a state predict the timing of bank regulatory reforms. Although we control for BHC, and hence state fixed effects, the management of LLPs by a state's banks might influence the timing of intrastate branch, interstate bank, and interstate branch deregulation. Thus, following the method developed in Kroszner and Strahan (1999), we examine whether the degree of discretionary LLPs by a state's BHCs predicts the timing of each type of bank regulatory reform. For each state and year, we aggregate discretionary LLPs by BHCs operating in the state. Specifically, to compute an index of discretionary LLPs in state $j$ during year $t$, we weight each BHC's discretionary LLPs by its proportion of assets in state $j$ 's banking system during year $t$. We then incorporate lagged values of this index into the Kroszner and Strahan (1999) econometric model for predicting bank regulatory reforms and assess if discretionary LLPs account for the timing of bank regulatory reforms. The Kroszner and Strahan (1999) framework includes the following control variables: GSP per capita, state level unemployment rate, small bank share of all banking assets, capital ratio of small banks relative to large ones, relative size of insurance in states where banks may sell insurance (zero otherwise), relative size of insurance in states where banks may not sell insurance (zero otherwise), an indicator variable that equal to one if banks may sell insurance (zero 
otherwise), the small firm (fewer than 20 employees) share of the number of firms in the state, an indicator variable that equals one if the state has a unit banking law (zero otherwise), share of state government controlled by Democrats, and an indicator that takes a value of one if the state is controlled by one party (zero otherwise).

Table 4 presents the results of the determinants of banking deregulations using OLS regressions. ${ }^{4}$ The sample consists of state-year observations from 1986 to 2006, and we therefore exclude states that deregulated before 1986. While all states deregulated interstate branching restrictions after 1986, only 22 and 20 states started removing restrictions on interstate banking and intrastate branching in or after 1986, respectively. The dependent variables used in Table 4 are INTER, Ln(\# of Out-Of-States), Ln(\# of Out-Of-States Distance Weighted), Ln(\# of BHCs from Out-Of-States), INTRA, and INTER-BRANCH.

As shown, discretionary LLPs do not predict the timing of any of the regulatory reforms. There is no evidence that the degree to which BHCs manipulate the information that they disclose to the public or regulators altered the decision of officials to eliminate restrictions on intrastate branching, eased regulatory impediments to interstate banking, or lowered barriers to interstate branching. ${ }^{5}$

\footnotetext{
${ }^{4}$ We obtain quantitatively similar results when using a probit model. However, due to the zero-variance problem, many observations are automatically dropped with the probit estimator.
} 


\section{Main Results}

\subsection{Bank Regulatory Reforms and Discretionary LLPS}

Table 3 presents regression results on the relationship between discretionary LLPs and bank regulatory reforms that lowered barriers to competition. In these baseline regressions, we study the different bank regulatory reform indicators one-at-a-time. That is, we first examine INTRA, which measures the relaxation of regulatory impediments to intrastate branching. We then consider the four measures of interstate bank deregulation-INTER, Ln(\# States), Ln(\#States-Distance Weighted), and Ln(\# BHCs from Other States). Finally, we examine INTER-BRANCH, which measures the removal of barriers to BHCs establishing bank branches across state lines. All six regressions control for time-varying BHC characteristics (logSIZE, LLP_lag, LOSS, and CAP), time fixed effects, and BHC fixed effects. In parentheses, we report heteroskedasticity consistent standard errors (as defined in MacKinnon and White (1985)) that are clustered at the state-quarter level. These regressions assess the impact of regulatory reforms that eased competition among banks on disclosure quality.

The results indicate that these regulatory reforms reduced discretionary LLPs. Each of the six indicators of regulatory reform enters negatively and statistically significantly at the one percent level. Thus, disclosure quality rose after states eased restrictions on the ability of its banks to establish branch networks across the state (INTRA). Similarly, after a state started allowing BHCs from other states to enter its borders and establish subsidiaries (INTER), discretionary LLPs fell. Furthermore, as reported in columns 2-4 of Table 3, each of three dynamic measures of the evolution of interstate bank deregulation enters negatively and significantly: as states allowed BHCs from more states to enter, discretionary LLPs fell. Finally, as indicated by the results on INTER-BRANCH, after states allowed BHCs from other 
states to enter via the establishment of branches (not just via separately capitalized subsidiaries), the manipulation of LLPs dropped, too. ${ }^{6}$

The estimated coefficients reported in Table 3 suggest that the economic impact of bank deregulation on the management of LLPs is large. For example, the point estimate for the effect of the start of interstate bank deregulation (INTER) on discretionary LLPs is -0.47 (column 1), which implies a $47 \%$ decrease in abnormal LLPs after a state starts to remove barriers to interstate banking. Similarly, after a state eliminated restrictions on intrastate branching, discretionary LLPs fell by $83 \%$, as reported in column 5 . The results suggest an economically large, negative relationship between removing barriers to competition and the management of LLPs.

With respect to the control variables, Table 3 indicates the following. Large BHCs tend to engage in more LLP management. This is consistent with the findings in Huizinga and Laeven (2012) who showed that larger banks have more discretion over asset valuation because they tend to have a larger fraction of hard-to-value assets, therefore, these banks tend to benefit more from the enhanced capability to do asset revaluation. We also find that discretionary LLPs are positively related to LOSS (i.e. an indicator variable takes the value of one if net income is negative and zero otherwise). These results suggest that when the bank makes a loss, there is an uptick in the management of LLPs. This result is consistent with findings in the earnings smoothing literature that banks manage income by either delaying or accelerating provisions for losses (Liu and Ryan, 2006).

\footnotetext{
6 These findings also relate to research on bank opacity. Campbell and Kracaw (1980), Berlin and Loeys (1988), Morgan (2002), and Flannery et al. (2004) examine the comparative opacity of banks and nonfinancial firms. Rather than assess comparative opacity, we examine the impact of regulatory reforms that fostered competition on bank opacity.
} 


\subsection{BHC-specific regulatory environment and discretionary $L L P$}

There is a potentially important limitation to these state-time regulatory reform measures: They are not computed at the BHC-time level. Although considerable research finds that these regulatory reforms spurred competition among banks, this does not necessarily imply that these reforms reduced abnormal accruals of LLPs by intensifying competition. Perhaps, deregulation produced other changes that reduced discretionary LLPs, and it is these other changes - not increased competition - that accounts for the improvement in disclosure quality.

In light of this concern, we develop a new strategy for more precisely identifying the impact of competition on bank behavior. This strategy builds on the "gravity model," which predicts that the costs to a business of opening a new site are positively associated with the distance between the business's headquarters and the site. For example, after state $j$ allows BHCs in state $i$ to enter and establish subsidiaries in state $j$, two subsidiaries in state $j$ may face different competitive pressures from state $i$, depending on their distance to state $i$. More concretely, when California deregulates with Arizona, the banks in southern California may face greater competitive pressures from BHCs in Arizona than banks in northern California. A large body of evidence validates the "gravity model" by showing that distance influences such investment decisions, including the decision of BHCs to open subsidiaries in other states (Goetz et al., 2013, 2014). We build a BHC-specific-time measure of deregulation-induced competition by integrating this gravity model into the process of interstate bank deregulation.

More formally, we first construct measures of the competitive environment associated with interstate banking facing each subsidiary. For each subsidiary in each period, we identify those states whose BHCs can enter the subsidiary's state. We then weight each of those states by the inverse of its distance to the subsidiary. That is, we calculate the interstate bank competitive pressures facing a subsidiary, $s$, located in state $j$ in period $t$ as:

$$
C_{s, j, t}^{S U B}=\sum_{i}\left[I_{j, i, t} / D I S_{s, i}\right],
$$


where $\boldsymbol{I}_{j, i, t}$ equals one if BHCs from state $i$ are allowed to establish subsidiaries in state $j$ in period $t$, and zero otherwise; and, $\boldsymbol{D} \boldsymbol{I} \boldsymbol{S}_{s, j}$ equals the distance between subsidiary s and state $i$. Second, we aggregate this to the BHC level and calculate the interstate bank competitive pressures facing $\mathrm{BHC}, b$, located in state $k$ in period $t$. We do this by identifying all of the subsidiaries in each BHC, i.e., all $s$ within each $b$, and performing the following calculation:

$$
B H C_{-} D I S_{b, k, t}=\sum_{s \in b} \operatorname{Ln}\left[C_{s, j, t}^{s U B}\right] * P_{s, b, t}, 7
$$

where $\boldsymbol{P}_{s, b, t}$ is the proportion of assets of each subsidiary, $s$, within BHC, $b$, in period $t$, relative to the total assets of all of $\mathrm{BHC} b$ 's subsidiaries. Thus, for each $\mathrm{BHC}$ in each period:

$$
1=\sum_{s \in b} P_{s, b, t}
$$

We also create two additional BHC-specific-time measures where we also weight by the economic sizes of different states (Gross State Product) and the number of BHCs in states. We call these $B H C_{-} D I S \_G S P$ and $B H C_{-} D I S \_N U M$, respectively. To illustrate the construction we $B H C_{-} D I S \_G S P$, we modify the computation of the regulatory-induced competitive pressures facing each subsidiary in each period:

$$
C_{s, j, t}^{S U B}=\sum_{i}\left[G S P_{j}^{*} I_{j, i, t} / D I S_{s, i}\right] .
$$

We then proceed as above to construct BHC_DIS_GSP.

A novel component of this approach is that it measures the changing competitive environment facing a $\mathrm{BHC}$ as the BHC's subsidiaries in other states facing different competitive pressures. For example, a BHC headquartered in state $i$ with subsidiaries in other states will experience changes in competition as those other states deregulate, subjecting the $\mathrm{BHC}$ to greater competition. In computing these BHC-specific-time competition measures

\footnotetext{
${ }^{7}$ In those cases where $C_{S, j, t}^{S U B}=0$, we include the value as 0.001 .
} 
based on regulations and distance, we also calculate and examine other measures that incorporate information on the economic sizes of different states.

With these BHC specific measures, we reexamine the regulatory determinants of bank opacity. In particular, we modify equation (2), so that it now simultaneously includes (a) the original state-time indicators of interstate banking reforms and (b) these new BHC-specific-time measures of the competitive environment facing BHCs.

$$
\text { Discretionary } L L P_{b j t}=\alpha_{t}+\alpha_{b}+\beta^{\prime} \cdot D_{j t}+\delta^{\prime} B H C_{-} D I S_{b j t}+\gamma^{\prime} \cdot X_{i j t}+\varepsilon_{i j t} \text {, }
$$

If (a) the earlier results were driven by competition and (b) the distance of a potential competitor to a market influences the competitiveness of that market, then $\delta$ should enter negatively and significantly. If, however, the earlier results were driven by a change in some state-time factor occurring when two states lower barriers to interstate banking, then the BHC-specific-time measure of competition should not provide additional explanatory power in the discretionary LLP analyses.

The results reported in Table 5 indicate that interstate bank deregulation reduced discretionary LLP by intensifying the competitive pressures facing BHCs. In columns 1-3 of Table 5, we first include three BHC-specific deregulation measures (BHC_DIS, BHC_DIS_GSP, and BHC_DIS_NUM) separately into the regression. As shown, they each enter negatively and significantly. In columns 4-6, we further control for the interstate deregulation dummy variable INTER, which equals one after a state first deregulates with any other state. Consistent with the competition channel, we find that each of the three BHC-specific deregulation measures enters negatively and significantly. Finally, in columns 7-9, we control for the evolution of interstate deregulation at the state level (Ln(\# of States)). Again, even when controlling for the dynamic process of interstate bank deregulation at the state-time level, we continue to find that the BHC-specific distance weighted measures of the 
competitive environment facing each BHC (BHC_DIS, BHC_DIS_GSP, and BHC_DIS_NUM) enter negatively and significantly. The evidence is consistent with the view that regulatory reforms that intensify the competition faced by a BHC tend to reduce the BHC's discretionary LLPs.

\section{Extensions and Robustness Tests}

\subsection{Alternative Measures of Discretionary Loan Loss Provisions}

We considered alternative measures of the degree to which banks manipulate information disclosed to the public and regulators. In this subsection, we use different models of loan loss provisioning, collect the residuals from these models, and compute the logarithm of the absolute value of the residuals as alternative proxies of discretionary LLPs. Specifically, we use four additional models described in Beatty and Liao (2014). The first two models are simple modifications of their preferred model of LLPs:

Model (a) in Beatty and Liao (2014):

$$
\begin{aligned}
& L L P_{i j t}=\alpha_{0}+\alpha_{1} d N P A_{i, j, t+1}+\alpha_{2} d N P A_{i j t}+\alpha_{3} d N P A_{i, j, t-1}+\alpha_{4} d N P A_{i, j, t-2}+ \\
& \alpha_{5} S I Z E_{i, j, t-1}+\alpha_{6} d L O A N_{i j t}+\alpha_{7} \operatorname{CSRET}_{j t}+\alpha_{8} d G S P_{j t}+\alpha_{9} d U N E M P_{j t}+\alpha_{10}\left\{D_{j t}\right\}+ \\
& \varepsilon_{i j t},
\end{aligned}
$$

Model (b) in Beatty and Liao (2014):

$$
\begin{aligned}
& L L P_{i j t}=\alpha_{0}+\alpha_{1} d N P A_{i, j, t+1}+\alpha_{2} d N P A_{i j t}+\alpha_{3} d N P A_{i, j, t-1}+\alpha_{4} d N P A_{i, j, t-2}+ \\
& \alpha_{5} \operatorname{SIZE}_{i, j, t-1}+\alpha_{6} d L O A N_{i j t}+\alpha_{7} \operatorname{CSRET}_{j t}+\alpha_{8} d G S P_{j t}+\alpha_{9} d U N E M P_{j t}+ \\
& \alpha_{10} A L W_{i, j, t-1}++\alpha_{11}\left\{D_{j t}\right\} \varepsilon_{i j t}
\end{aligned}
$$

The next two models are examined in Beatty and Liao (2014), where one is from Kanagaretnam et al. (2010):

$$
\begin{aligned}
& L L P_{i j t}=\alpha_{0}+\alpha_{1} A L W_{i, j, t-1}+\alpha_{2} N P A_{i, j, t-1}+\alpha_{3} C_{i j t}+\alpha_{4} d L O A N_{i j t}+\alpha_{5} L O A N_{i j t}+ \\
& \alpha_{6} \operatorname{CSRET}_{j t}+\alpha_{7} d G S P_{j t}+\alpha_{8} d U N E M P_{j t}+\alpha_{9}\left\{D_{j t}\right\}+\varepsilon_{i j t},
\end{aligned}
$$


The other and the final model is from Bushman and Williams et al. (2012):

$$
\begin{aligned}
& L L P_{i j t}=\alpha_{0}+\alpha_{1} d N P A_{i, j, t+1}+\alpha_{2} d N P A_{i j t}+\alpha_{3} d N P A_{i, j, t-1}+\alpha_{4} d N P A_{i, j, t-2}+ \\
& \alpha_{5} S I Z E_{i, j, t-1}+\alpha_{6} d G S P_{j t}++\alpha_{7}\left\{D_{j t}\right\}+\varepsilon_{i j t}
\end{aligned}
$$

All of these models also include state fixed effects in predicting abnormal LLPs. As shown in Appendix Table 3, these alternative measures of discretionary LLPs yield the same conclusions: Regulatory reforms that spurred competition among banks tended to reduce the management of LLPs. ${ }^{8}$ Our main results in general still hold. Using various model specifications, we find that the point estimate for the effect of interstate bank deregulation ranges from -0.2013 to -0.3613 (columns 1-4), which implies about 20-36\% decrease in abnormal accrual compared to its sample average for treated BHCs relative to their control group. Thus, the economic sizes of the relationship between regulatory reforms and the reduction in discretionary LLPs are comparable to our main results based on the preferred measure of abnormal accruals of LLPs.

\footnotetext{
${ }^{8}$ For brevity, we only include the analyses with two measures of interstate bank deregulation, INTER and Ln(\# of states). The results are similarly robust to using the other two measures. Also, the number of observations is slightly lower in Appendix Table 3 relative to Tables 3 because one of the new models uses $N P A_{i, j, t-2}$. With the two-period lag, there is a loss of observations and we keep the number of observations constant across the Appendix Table 3 specifications.
} 


\subsection{A Different Measure of Information Manipulation}

Rather than inferring the degree to which banks manipulate information disclosed to the public by using the residuals of an empirical model of LLPs, we also examined the frequency with which banks restate their earnings. When a bank restates earnings, it means that the bank either intentionally or unintentionally misstated earnings in the past. Such restatements could simply reflect a change in accounting standards or a mistake, and few restatements are criminally fraudulent. Nevertheless, restatements do represent a violation of appropriate accounting practices by managers and represent an alternative proxy of the management of information disclosed to the public.

Following Beatty and Liao (2014), we manually search restatement information in 8-K, 10-K, and 10-Q files from EDGAR directly. ${ }^{9}$ We create an indicator variable (RESTATEMENT) that equals one if a BHC restated its earnings in a year and zero otherwise. Consequently, we conduct these analyses using annual data. Even though EDGAR's electronic files start in year 1996, our search through EDGAR's paper records go back to 1988. However, the comprehensiveness and quality of the data increased markedly since 1993. We therefore start our sample period from 1993 through 2006 in conducting the restatement analysis, though the results are robust to choosing alternative sample periods. These data limitations prevent us from conducting the analyses on intrastate branch or interstate deregulation. In this section, we therefore only examine the relationship between interstate branch deregulation and bank restatements. Given the binary distribution of the

\footnotetext{
${ }^{9}$ We primarily follow Audit Analytics in classifying both fraud and some technical and nonsubstantive restatements as financial restatement cases in our hand-collection procedure. These technical or nonsubstantive restatements are related to company reorganizations and restructurings. In addition, we also consider issues related to accounting rules change or reclassification as earnings restatement. More specifically, we count the following non-fraud cases as financial restatement reported in EDGAR: adjustment due to mergers and acquisitions; adjustment due to new accounting principles; adjustment in income statement, balance sheet, or cash flow statement; adjustment due to reclassification or characterization; adjustment due to internal management policies, methodology change, segment revision, allocation between lines of business, measurement change; adjustment due to tax impacts; Adjustment due to error / correction; adjustment due to operation combination / operation closed / operation sales; adjustment due to loans, assets, credit changes, investment; adjustment due to warrants, securities, equity changes; adjustment in cash dividends; adjustment in share outstanding, stock value, stock dividends, or stock distribution; earnings per share or dividends adjustment because of stock split; earnings per share adjustment or other adjustment because of dividends payment.
} 
dependent variable, we use a probit regression model and report the marginal effects. We confirm the results using OLS. In the analyses, we control for year and BHC fixed effects.

As reported in Table 6, interstate branch deregulation reduced the odds of banks restating their earnings. The coefficient estimates in columns 1 indicate that the passage of the IBBEA deregulation reduces the odds of banks' earnings restatement by $10 \%$, holding everything else constant. A drawback of using the probit model with fixed effects is the potential incidental parameters problem (Neyman and Scott, 1948). The fixed effects model draws inferences about common parameters and places very little structure on the distribution of unobserved heterogeneity. However, using a nonlinear model, such as probit model, noise in the estimation of individual level effects will contaminate estimates of the common parameters when the time dimension is short. In addition, in our case, many observations are automatically dropped from the regression due to the zero within-variance problem. We therefore also run a set of OLS regressions using similar specifications to check the robustness of our results and report the OLS estimates in column 2 of Table 6 . We find that the marginal effects of interstate branch deregulation on reducing the odds of earnings restatement is about $6 \%$. These results are not only statistically significant, but also similar in terms of magnitude compared to those estimates from the probit model.

In columns 3-4 of Table 6, we also present the dynamic effects of the interstate branch deregulation on the odds of financial restatement, where financial restatement is modeled by leads and lags from two years before to eight years or more after the interstate branch deregulation. The reference group is the interstate branch deregulation year.

These analyses show that (1) changes in financial restatements do not occur before deregulation, (2) deregulation triggers a reduction in financial restatements, and (3) the impact of deregulation on restatement grows over time. The post-deregulation coefficients starting from the second year are negative and statistically significant at the 5\% level. 


\subsection{Other Robustness Tests}

Besides the robustness tests discussed above, we conducted a series of sensitivity analyses to assess the sensitivity of the results. To save space, we describe these robustness tests but do not present the regression results, which are available upon request.

First, we were concerned that the management of information might have changed after the 2004 Basel II Accord because it required more stringent risk-based capital requirements. Thus, we re-did the analyses restricting the sample to before 2004. The results hold for this restricted sample period and the coefficient estimates are very similar.

Second, Liu and Ryan (2006) argue that the ability of banks to manage earnings is constrained by whether they hold homogeneous or heterogeneous loans. To confirm our results from the baseline regression are robust to the loan heterogeneity, we include additional loan type control variables. Specifically, we control for loans secured by real estate, commercial and industrial loans, loans to finance agricultural production, individual loans, and loans to foreign governments, where all of the loan type variables are scaled by the size of total loans. Controlling for the nature of the different loans yields very similar results, both in terms of significance and in terms of the economic sizes of the coefficient estimates.

Third, we examined discretionary LLPs at the subsidiary bank level. There are material disadvantages to conducting the analyses at the subsidiary level. First, a BHC's subsidiaries are probably subject to the same accounting policies as the parent organization. Second, subsidiaries are typically not publicly listed, so that market capitalization and other data are typically unavailable for subsidiary banks. One advantage of conducting the analyses at the subsidiary level, however, is that we can identify exactly which bank subsidiary is influenced by the interstate banking deregulation.

To do the subsidiary-level analyses, we use the commercial bank dataset published on the Federal Reserve Bank of Chicago website to merge these subsidiary banks with BHCs in our main sample. We exclude those stand-alone banks or banks that do not belong to any BHCs. We end up with a sample of 68,320 bank-quarter observations. However, because some of the banks are lack of capitalization information, our final subsidiary bank data 
contains 56,129 observations, with 2,931 subsidiary banks spanning from the third quarter of 1986 until 2006. Again, we have excluded the state of Delaware and South Dakota from the sample. These subsidiary banks belong to 888 BHCs (out of 911 BHCs) in our main sample. The results using the BHC subsidiaries are virtually identical to those using the consolidated BHC. The results are similar both in terms of coefficient estimates and in terms of statistical significance.

Finally, there is considerable exit and entry over this period of active merger and acquisition activity this deregulatory period. To assess whether selection on particular traits drives our findings, we conduct the analyses only for BHCS that exists for the full sample. All of the results hold.

\section{Conclusion}

In this paper, we find that bank regulatory reforms that eased impediments to competition among U.S. BHCs reduced abnormal accruals of LLPs. This paper contributes to our understanding of how regulations influence the private governance and regulatory oversight of banks. Theory provides conflicting predictions about the impact of regulatory reforms that intensify competition on bank opacity. Some models predict that competition will induce the executives of banks to manipulate information either to hinder the entry of potential competitors or to extract as many private rents as possible in the short-run because competition makes the long-run viability of the bank uncertain. Other models stress that competition will enhance efficiency, reduce managerial slack, and force banks to disclose more accurate information.

The evidence suggests that bank deregulations that removed barriers to the geographic expansion of banks boosted disclosure quality by intensifying competition among banks. There is no evidence that intensifying competition makes it more difficult for private investors to discipline banks or regulators to supervise them. The findings are consistent with the view that exposing BHCs to greater competition will facilitate the monitoring of banks, with potentially beneficial repercussion on the governance and regulation of banks. 


\section{References}

Ahmed, A., Takeda, C., Thomas, S., 1999. Bank loan loss provisions: A reexamination of capital management and signaling effects. Journal of Accounting and Economics 28, $1-25$.

Ali, A., Klasa, S., Yeung, E., 2009. The limitations of industry concentration measures constructed with Compustat data: Implications for finance research. Review of Financial Studies 22, 3839-3871.

Barth, J.R., Caprio, G., Levine, R., 2004. Bank regulation and supervision: What works best? Journal of Financial Intermediation 13: 205-248.

Barth, J.R., Caprio, G., Levine, R., 2006. Rethinking bank regulation: Till angels govern, Cambridge: Cambridge University Press.

Barth, J.R., Lin C., Lin P., Song F., 2009. Corruption in bank lending to firms: Cross-country micro evidence on the beneficial role of competition and information sharing, Journal of Financial Economics 91, 361-388.

Beatty, A., Chamberlain, S., Magliolo, J., 1995. Managing financial reports of commercial banks: The influence of taxes, regulatory capital, and earnings. Journal of Accounting Research 33(2): 231-261.

Beatty, A., Ke, B., Petroni, K.R. 2002. Earnings management to avoid earnings declines across public and privately held banks. The Accounting Review 77: 547-70.

Beatty, A., Liao, S., 2011. Do delays in expected loss recognition affect banks' willingness to lend? Journal of Accounting and Economics 52, 1-20.

Beatty, A., Liao, S. 2014. Financial accounting in the banking industry: A review of the empirical literature. Journal of Accounting and Economics, forthcoming.

Beck, T., Demirguc-Kunt, A. Levine, R., 2006. Bank Supervision and Corruption in Lending. Journal of Monetary Economics, 53: 2131-2163.

Beck, T., Levine, R., Levkov, A., 2010. Big bad banks? The winners and losers from bank deregulation in the United States. Journal of Finance 65: 1637-67.

Beck, T., Levine, R., Loayza, N., 2000. Finance and sources of growth. Journal of Financial Economics 58: 261-300.

Berger, P. G., 2011. Challenges and opportunities in disclosure research: A discussion of 'the financial reporting environment: Review of the recent literature. Journal of Accounting and Economics 51, 204-218. 
Berlin, M., Loeys, J., 1988. Bond covenants and delegated monitoring. Journal of Finance 43, $397-412$.

Bushman, R. M., Williams, C. D. 2012. Accounting discretion, loan loss provisioning, and discipline of banks' risk-taking. Journal of Accounting and Economics 54: 1-18.

Campbell, T.S., Kracaw, W.A., 1980. Information production, market signaling, and the theory of intermediation. Journal of Finance 35, $863-882$.

Cohen, L.J., Cornett, M.M., Marcus, A.J., Tehranian, H., 2014. Bank earnings management and tail risk during the financial crisis. Journal of Money, Credit and Banking 46, 171-197.

Collins, J., Shackelford, D., Wahlen, J., 1995. Bank differences in the coordination of regulatory capital, earnings, and taxes. Journal of Accounting Research 33, 263-291.

Darrough, M., Stoughton, N., 1990. Financial disclosure policy in an entry game. Journal of Accounting and Economics 12: 219-43.

Dechow, P.W., Sloan, R., Sweeney, A., 1995. Detecting earnings management. The Accounting Review, 70: 193-226.

Dechow, P.W., Ge, W., 2006. The Persistence of Earnings and Cash Flows and the Role of Special Items: Implications for the Accrual Anomaly," Review of Accounting Studies $11,253-296$.

Dechow, P.W., Ge, W., Schrand, C., 2010. Understanding earnings quality: A review of the proxies, their determinants and their consequences. Journal of Accounting and Economics 50, 344-401.

Demyanyk, Y., Ostergaard, C., Sørensen, B. E. 2007. U.S. banking deregulation, small businesses, and interstate insurance of personal income. Journal of Finance 62: 2763801.

Dichev, I., Graham, J., Harvey, C., Rajgopal, S., 2013. Earnings quality: Evidence from the field. Journal of Accounting and Economics 56, 1-33.

Flannery, M. J., Kwan, S. H., Nimalendran, M. 2004. Market evidence on the opaqueness of banking firms' assets. Journal of Financial Economics 71, 419 - 460.

Goetz, M. R., Laeven, L., Levine, R. 2013. Identifying the valuation effects and agency costs of corporate diversification: Evidence from the geographic diversification of U.S. banks. Review of Financial Studies 26: 1787-823. 
Goetz, M.R., Laeven, L., Levine, R. 2014. Does the geographic expansion of bank assets reduce risk? University of California, Berkeley, mimeo.

Hart, O.D., 1983. The market mechanism as an incentive scheme. Bell Journal of Economics 14: $366-82$.

Holmstrom, B., 1982. Moral hazard in teams. The Bell Journal of Economics 13, 324-340.

Huizanga, H., Laeven, L., 2012. Bank valuation and accounting discretion of banks during a financial crisis. Journal of Financial Economics 106, 614-634.

Jayaratne, J., Strahan, P.E. 1996. The finance-growth nexus: Evidence from bank branch deregulation. Quarterly Journal of Economics 111: 639-70.

Jayaratne, J., Strahan, P.E., 1998. Entry restrictions, industry evolution, and dynamic efficiency: Evidence from commercial banking. Journal of Law and Economics 41: 239-73.

Jiang, J., Petroni, K., Wang, I., 2010. CFOs and CEOs: who have the most influence on earnings management? Journal of Financial Economics 96, 513-526.

Johnson, C., Rice, T., 2008. Assessing a decade of interstate bank branching. The Washington and Lee Law Review 65, 73-127.

Kanagaretnam, K., Krishnan, G.V., Lobo, G.J., 2010. An empirical analysis of auditor independence in the banking industry. The Accounting Review 85, 6: 2011-46.

Kedia, S., Philippon, T., 2009. The economics of fraudulent accounting. Review of Financial Studies 22, 169-99.

King, R.G., Levine, R., 1993a. Finance and growth: Schumpeter might be right. Quarterly Journal of Economics 108, 717 - 738.

King, R.G., Levine, R., 1993b. Finance, entrepreneurship, and growth: Theory and evidence. Journal of Monetary Economics 32, 513 - 542.

Kroszner, R. S., Strahan, P. E., 1999. What drives deregulation? Economics and politics of the relaxation of bank branching restrictions. Quarterly Journal of Economics 114: 1437-67.

Liu, C., Ryan, S.G., 2006. Income smoothing over the business cycle: Changes in banks' coordinated management of provisions for loan losses and loan charge-offs from the pre-1990 bust to the 1990s boom. The Accounting Review 81: 421-41. 
MacKinnon, J. G., White, H., 1985. Some heteroskedastic-consistent covariance matrix estimators with improved finite sample properties. Journal of Econometrics 29 (2): 305325.

Morgan, D. P., 2002. Rating Banks: Risk and Uncertainty in an Opaque Industry. The American Economic Review 92, 874-888.

Morgan, D. P., Rime, B., Strahan, P. E., 2004. Bank integration and state business cycles, Quarterly Journal of Economics 119: 1555-85.

Neyman, J., Scott, E.L., 1948. Consistent Estimates Based on Partially Consistent Observations, Econometrica, 16: 1-32.

Rice, T., Strahan, P.E., 2010. Does credit competition affect small-firm finance. Journal of Finance 65: 861-89.

Scharfstein, D., 1988. The disciplinary role of takeovers. Review of Economic Studies 55: 185-99.

Schmidt, K.M., 1997. Managerial incentives and product market competition. Review of Economic Studies 64, 191-213.

Shleifer, A., 2004. Does competition destroy ethical behavior? American Economic Review 94, 2: 414-418.

Shleifer, A., Vishny, R., 1997. A survey of corporate governance. Journal of Finance 52, 737-783.

Stein, J., 1989. Efficient capital markets, inefficient firms: A model of myopic corporate behavior. Quarterly Journal of Economics 104, 655-669.

Stiroh, K.J., Strahan, P.E., 2003. Competitive dynamics of deregulation: Evidence from U.S. banking. Journal of Money, Credit and Banking 35: 801-828.

Von Thadden, E.L., 1995. Long-term contracts, short-term investment and monitoring. Review of Financial Studies 62, 557-575.

Wagenhofer, A., 1990. Voluntary disclosure with a strategic opponent. Journal of Accounting and Economics 12: 341-63.

Yu, F., 2008. Analyst coverage and earnings management. Journal of Financial Economics $88,245-271$. 


\section{Figure 1: Evolution of Discretionary LLPs around Interstate Bank Deregulation}

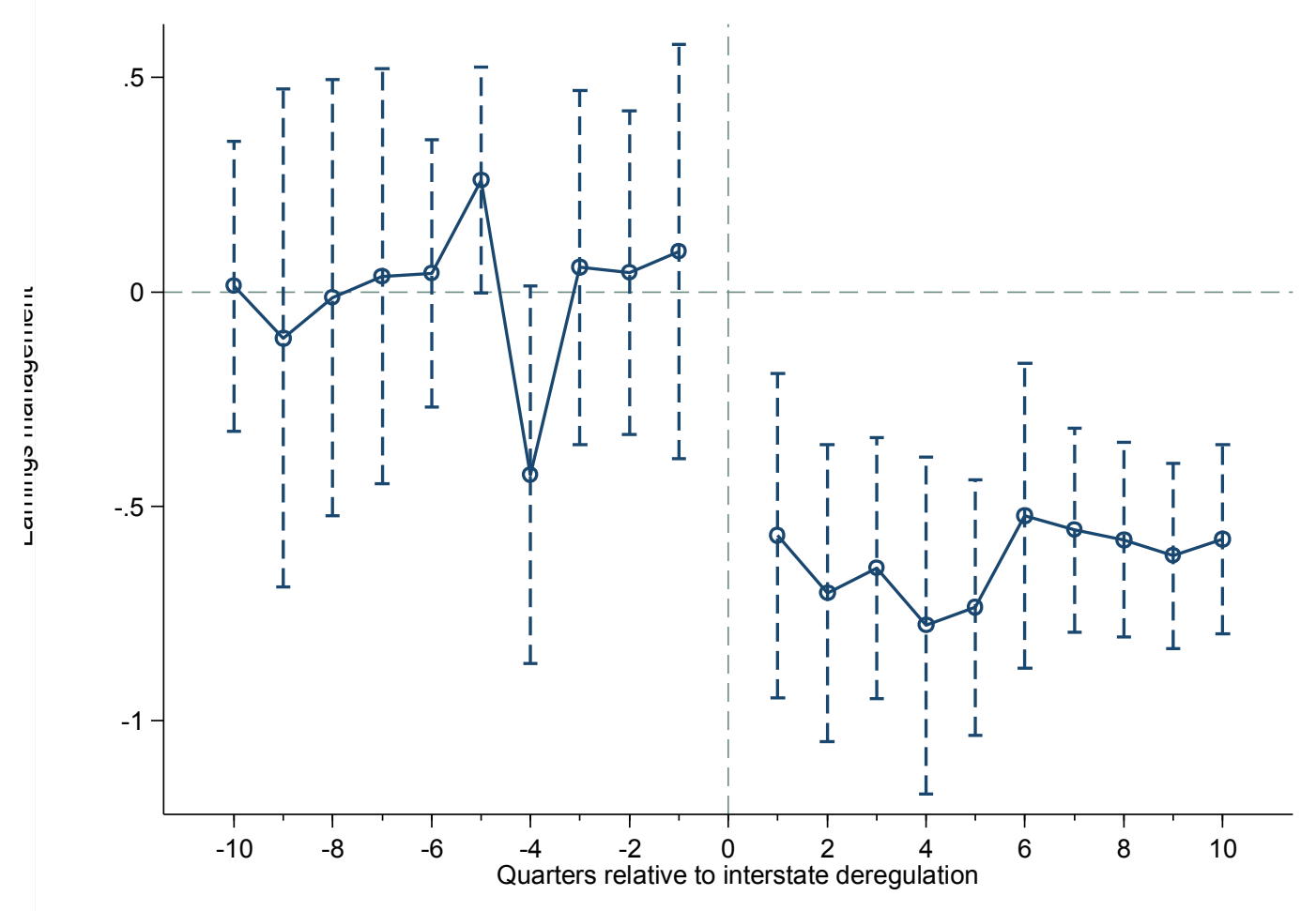

Note: This figure plots the impact of interstate bank deregulation on discretionary LLPs by banks in a state. For each state, year zero is the year the state started interstate bank deregulation, such that one quarter before deregulation is -1 and one quarter after deregulation is +1 . We consider a 20 -quarter window, spanning from ten quarters before until ten quarters after deregulation. The figure reports estimated coefficients from the following regression:

$$
\text { Discretionary } L L P_{i t}=\alpha_{t}+\alpha_{i}+\beta_{1} D_{i t}^{-10}+\beta_{2} D_{i t}^{-9}+\cdots+\beta_{20} D_{i t}^{+10}+\varepsilon_{i t},
$$

where the deregulation dummy variable $\mathrm{D}_{\mathrm{it}}^{+\mathrm{n}}$ equals one for banks in the $n$th quarter after deregulation, and the deregulation dummy variable $\mathrm{D}_{\text {it }}^{-\mathrm{n}}$ equals one for banks in the $n$th quarter before deregulation, and $\alpha_{t}$ and $\alpha_{i}$ are state-quarter and BHC fixed effects, respectively. The solid line denotes the estimated coefficients $\left(\beta_{1}, \beta_{2}, \ldots\right)$, while the dashed lines represent $95 \%$ confidence intervals. The graph is normalized by the pre-deregulation (period -10 through -1) mean. 


\section{Figure 2: Discretionary LLPs over EBTP around Interstate Bank Deregulation}

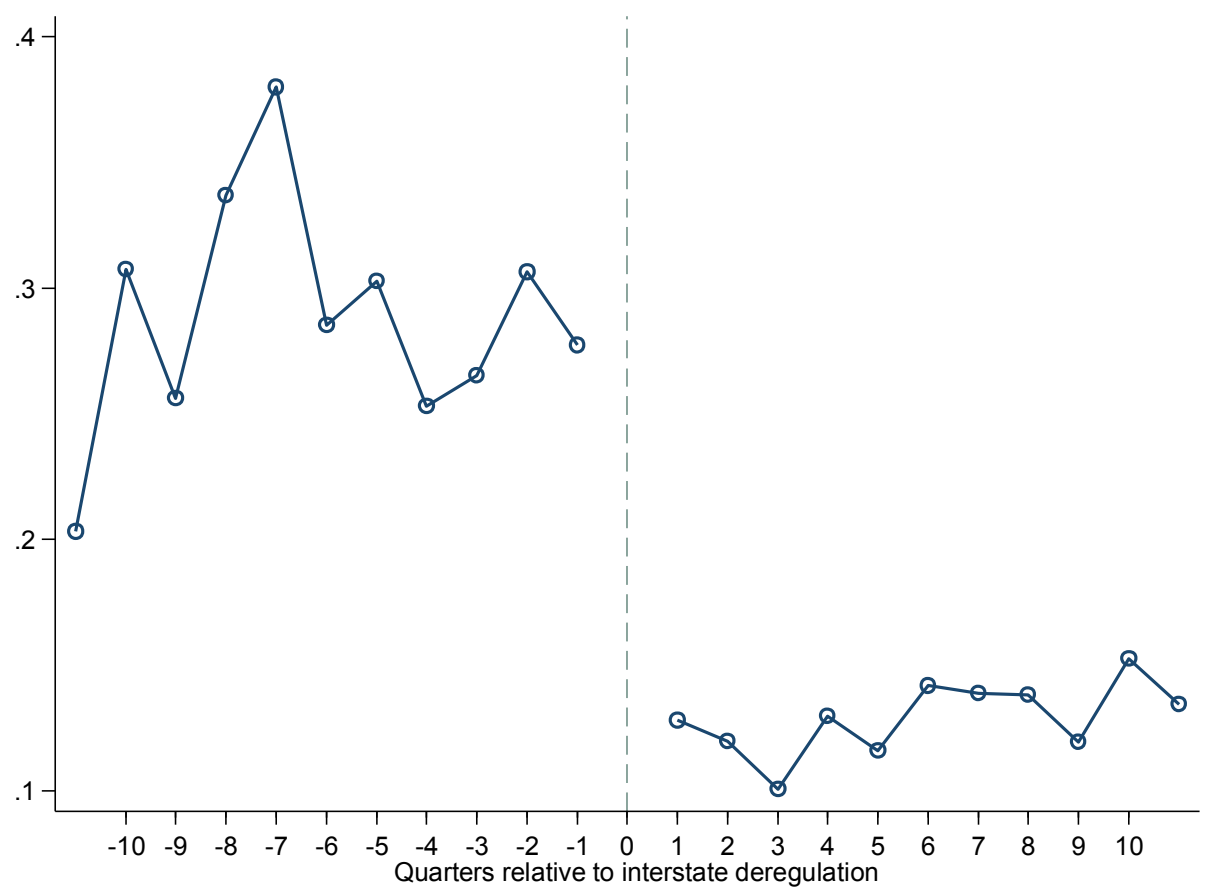

Note: This figure plots the impact of interstate bank deregulation on discretionary LLPs (scaled by EBTP) by BHCs in a state. For each state, year zero is the year the state started interstate bank deregulation, such that one quarter before deregulation is -1 and one quarter after deregulation is +1 . We consider a 20 -quarter window, spanning from ten quarters before until ten quarters after deregulation. The figure reports the median of the absolute value of discretionary LLPs divided by EBTP. EBTP is defined as income before taxes, provisions recognized in income (in million \$), and discretionary LLP is the absolute value of discretionary LLPs estimated from equation (1) multiplied by the value of the lag of total loans (in million \$). 


\section{Table 1. Variable Definition}

\section{Panel A. Definitions of Variables Used in Discretionary LLP Regressions}

\begin{tabular}{|c|c|}
\hline Variable Name & Definition \\
\hline \multicolumn{2}{|l|}{ Deregulation Measures } \\
\hline INTER & $\begin{array}{l}\text { A dummy variable equal to one if a } \mathrm{BHC} \text { is headquartered in a state that has passed an } \\
\text { interstate bank deregulation, and zero otherwise. }\end{array}$ \\
\hline INTRA & $\begin{array}{l}\text { A dummy variable that equals one if a } \mathrm{BHC} \text { is headquartered in a state that has } \\
\text { removed restrictions on intrastate branching through mergers and acquisitions, and } \\
\text { zero otherwise. }\end{array}$ \\
\hline INTER-BRANCH & $\begin{array}{l}\text { A dummy variable that equals one if the } \mathrm{BHC} \text { is headquartered in a state that has } \\
\text { liberalized restrictions on BHCs in others from establishing bank branches. }\end{array}$ \\
\hline $\operatorname{Ln}(\#$ of States) & $\begin{array}{l}\text { The natural logarithm of one plus the number of states whose BHCs can enter into the } \\
\text { home state in period } t \text {. }\end{array}$ \\
\hline Ln(\# of States - Distance & The natural logarithm of one plus the number of other states whose can enter the home \\
\hline Weighted) & $\begin{array}{l}\text { state in period } t \text {, where each of those other states is weighted by the inverse of its } \\
\text { distance to the home state. }\end{array}$ \\
\hline $\mathrm{Ln}(\#$ of BHCs from Other States) & $\begin{array}{l}\text { The natural logarithm of one plus the number of BHCs from other states that can enter } \\
\text { the home state in period } t \text {. }\end{array}$ \\
\hline BHC_DIS & $\begin{array}{l}\text { Computed as follows: For each BHC in each period, weight its assets across all } \\
\text { subsidiaries by the regulatory environment facing each subsidiary (including the } \\
\text { subsidiaries in the state of the BHC's headquarters). To calculate the regulatory } \\
\text { environment facing each subsidiary in each year, we measure the distance from each } \\
\text { subsidiary bank to the capital of every other state, and for each subsidiary in a state } k \text {, } \\
\text { weight the interstate deregulation between state } k \text { and every other state in period } t \text { by } \\
\text { that subsidiary's distance to the other state. As before, we take the natural logarithm of } \\
\text { the sum of the weighted distance. }\end{array}$ \\
\hline BHC_DIS_NUM & $\begin{array}{l}\text { Computed as follows: For each BHC in each period, weight its assets across all } \\
\text { subsidiaries by the regulatory environment facing each subsidiary (including the } \\
\text { subsidiaries in the state of the BHC's headquarters). To calculate the regulatory } \\
\text { environment facing each subsidiary in each year, we measure the distance from each } \\
\text { subsidiary bank to the capital of every other state, and for each subsidiary in a state } k \text {, } \\
\text { weight the interstate deregulation between state } k \text { and every other state in period } t \text { by } \\
\text { that subsidiary's distance to the other state, and further weight by the number of BHCs } \\
\text { in the other state. As before, we take the natural logarithm of the sum of the } \\
\text { BHC-weighted distance. }\end{array}$ \\
\hline BHC_DIS_GSP & $\begin{array}{l}\text { Computed as follows: For each BHC in each period, weight its assets across all } \\
\text { subsidiaries by the regulatory environment facing each subsidiary (including the } \\
\text { subsidiaries in the state of the BHC's headquarters). To calculate the regulatory } \\
\text { environment facing each subsidiary in each year, we measure the distance from each } \\
\text { subsidiary bank to the capital of every other state, and for each subsidiary in a state } k \text {, } \\
\text { weight the interstate deregulation between state } k \text { and every other state in period } t \text { by } \\
\text { that subsidiary's distance to the other state, and further weight by the economic size } \\
\text { (GSP per capita in } \$ 10,000 \text { ) of each of the other state. As before, we take the natural } \\
\text { logarithm of the sum of the GSP-weighted distance. }\end{array}$ \\
\hline \multicolumn{2}{|r|}{ (О Бан } \\
\hline $\log \mathrm{SIZE}$ & The natural logarithm of total assets in million $\$$ \\
\hline LLP_lag & One year lag of loan loss provision scaled by beginning total loans \\
\hline LOSS & A dummy variable that equals one if net income is negative, and zero otherwise. \\
\hline CAP & Book value of equity over total assets \\
\hline EBTP & Income before taxes, provisions recognized in income in million U.S. dollars \\
\hline
\end{tabular}


Panel B. Definitions of Variables Used to Create Discretionary Loan Loss Provisions

\begin{tabular}{ll}
\hline Variable Name & Definition \\
\hline LLP & Loan loss provision over the quarter scaled by beginning total loans \\
NPA & Non-performing assets over the quarter scaled by beginning total loans \\
dNPA & Change in NPA over the quarter divided by beginning total loans \\
LOAN & Total loans over the quarter in million $\$$ \\
dLOAN & Change in total loans over the quarter divided by beginning total loans \\
LOAN_ASSETS & Total loans over the quarter divided by total assets \\
CO & Net charge offs over the quarter divided by beginning total loans \\
ALW & Loan loss allowance over the quarter divided by total loans \\
CSRET & The return on the Case-Shiller Real Estate Index over the quarter \\
dUNEMP & Change in unemployment rates over the quarter \\
dGSP & Change in GSP (gross state product) per capita over the quarter/100
\end{tabular}


Table 2. Summary Statistics

This table presents summary statistics on the main variables used in the paper. The sample consists of BHC-quarter observations from the third quarter of 1986 to 2006. See Table 1 for variable definitions.

\begin{tabular}{|c|c|c|c|c|c|c|}
\hline Variable & $\mathrm{N}$ & Mean & Std & $\mathrm{P} 25$ & Median & P75 \\
\hline INTER & 27137 & 0.98 & 0.14 & 1 & 1 & 1 \\
\hline INTRA & 27137 & 0.96 & 0.18 & 1 & 1 & 1 \\
\hline INTER-BRANCH & 27137 & 0.56 & 0.50 & 0 & 1 & 1 \\
\hline $\operatorname{Ln}(\#$ of States $)$ & 27137 & 3.43 & 1.80 & 3.5 & 3.91 & 3.91 \\
\hline $\operatorname{Ln}(\#$ of States - Distance Weighted $)$ & 27137 & 0.8 & 1.55 & 0.85 & 1.25 & 1.26 \\
\hline $\operatorname{Ln}$ (\# of BHCs from Other States) & 27137 & 6.76 & 2.16 & 6.93 & 7.32 & 7.36 \\
\hline BHC_DIS & 25803 & 0.70 & 1.76 & 0.85 & 1.25 & 1.26 \\
\hline BHC_DIS_NUM & 25803 & 4.08 & 2.19 & 4.25 & 4.74 & 4.81 \\
\hline BHC_DIS_GSP & 25803 & 1.99 & 1.92 & 2.01 & 2.57 & 2.66 \\
\hline SIZE & 27137 & 11,014 & 64318 & 477 & 1,067 & 3,569 \\
\hline $\operatorname{logSIZE}$ & 27137 & 7.34 & 1.59 & 6.17 & 6.97 & 8.18 \\
\hline LLP_lag (\%) & 27137 & 0.14 & 0.27 & 0.04 & 0.08 & 0.15 \\
\hline LOSS & 27137 & 0.04 & 0.21 & 0 & 0 & 0 \\
\hline CAP & 27137 & 0.09 & 0.04 & 0.07 & 0.08 & 0.1 \\
\hline LLP (\%) & 27137 & 0.14 & 0.27 & 0.04 & 0.08 & 0.15 \\
\hline NPA & 27137 & 0.01 & 0.02 & 0 & 0.01 & 0.02 \\
\hline dNPA (\%) & 27137 & -0.01 & 1.18 & -0.15 & -0.02 & 0.11 \\
\hline LOAN & 27137 & 5880 & 28,660 & 300 & 680 & 2180 \\
\hline dLOAN & 27137 & 0.03 & 0.09 & 0 & 0.02 & 0.05 \\
\hline LOAN_ASSETS & 27137 & 0.64 & 0.12 & 0.58 & 0.65 & 0.72 \\
\hline CO (\%) & 27137 & 0.15 & 0.24 & 0.03 & 0.08 & 0.16 \\
\hline ALW & 27137 & 0.02 & 0.01 & 0.01 & 0.01 & 0.02 \\
\hline CSRET & 27137 & 0.01 & 0.01 & 0.01 & 0.02 & 0.02 \\
\hline dUNEMP & 27137 & -0.02 & 0.03 & -0.2 & -0.1 & 0.1 \\
\hline dGSP & 27137 & 1.72 & 2.00 & 0.57 & 1.63 & 2.78 \\
\hline ЕВTP & 27137 & 31.89 & 171.54 & 1.18 & 3.02 & 9.89 \\
\hline
\end{tabular}




\section{Table 3. Discretionary Loan Loss Provisions and Deregulation:}

\section{Predicting D-LLP By Including Deregulation Measures}

This table presents results of the effects of banking deregulations on discretionary loan loss provisions. The sample consists of BHC-quarter observations from the third quarter of 1986 through 2006. The dependent variable, discretionary loan loss provisions, is measured as the natural logarithm of the absolute value of residuals from the following equation (1): $L L P_{i j t}=\alpha_{0}+\alpha_{1} d N P A_{i, j, t+1}+\alpha_{2} d N P A_{i j t}+\alpha_{3} d N P A_{i, j, t-1}+$ $\alpha_{4} S I Z E_{i, j, t-1}+\alpha_{5} d L O A N_{i j t}+\alpha_{6} C S R E T_{j t}+\alpha_{7} d G S P_{j t}+\alpha_{8} d U N E M P_{j t}+\alpha_{9} S T_{j}+\alpha_{10}\left\{D_{j t}\right\}+\varepsilon_{i j t}$, where $\left\{D_{j t}\right\}$ represents one of the six deregulation measures (INTER, Ln (\# of States), Ln (\# of States-Distance Weighted), Ln (\# of BHCs from Other States), INTRA, and INTER-BRANCH) corresponding to each of the deregulation measures used in columns 1-6 of this table. INTER is a dummy variable equal to one if a BHC is headquartered in a state that has passed an interstate bank deregulation, and zero otherwise. Ln (\# of States) is the natural logarithm of one plus the number of states whose BHCs can enter into the home state in period $t$. $L n$ (\# of States-Distance Weighted) is the natural logarithm of one plus the number of other states whose can enter the home state in period $t$, where each of those other states is weighted by the inverse of its distance to the home state. Ln (\# of BHCs from Other States) is the natural logarithm of one plus the number of BHCs from other states that can enter the home state in period $t$. INTRA is a dummy variable that equals one if a BHC is headquartered in a state that has removed restrictions on intrastate branching through mergers and acquisitions, and zero otherwise. INTER-BRANCH is a dummy variable that equals one if the BHC is headquartered in a state that has liberalized restrictions on BHCs in others from establishing bank branches. Table 1 defines the other regressors. Standard errors are heteroskedasticity-consistent, clustered at the state-quarter level, and reported in parentheses. $* * *$, and $* * *$ indicate significant at $10 \%, 5 \%$, and $1 \%$, respectively.

\begin{tabular}{|c|c|c|c|c|c|c|}
\hline & (1) & $(2)$ & (3) & $(4)$ & $(5)$ & $(6)$ \\
\hline INTER & $\begin{array}{c}-0.4716^{* * *} \\
(0.0796)\end{array}$ & & & & & \\
\hline $\operatorname{Ln}(\#$ of States) & & $\begin{array}{c}-0.0418 * * * \\
(0.0056)\end{array}$ & & & & \\
\hline Ln(\# of States - Distance Weighted) & & & $\begin{array}{c}-0.0509 * * * \\
(0.0074)\end{array}$ & & & \\
\hline Ln(\# of BHCs from Other States) & & & & $\begin{array}{c}-0.0374 * * * \\
(0.0046)\end{array}$ & & \\
\hline INTRA & & & & & $\begin{array}{c}-0.8341 * * * \\
(0.0589)\end{array}$ & \\
\hline INTER-BRANCH & & & & & & $\begin{array}{c}-0.6271^{* * *} \\
(0.0517)\end{array}$ \\
\hline $\log \mathrm{SIZE}$ & $\begin{array}{c}0.0719 * * * \\
(0.0269)\end{array}$ & $\begin{array}{c}0.0589 * * \\
(0.0259)\end{array}$ & $\begin{array}{c}0.0587 * * \\
(0.0261)\end{array}$ & $\begin{array}{c}0.0575 * * \\
(0.0261)\end{array}$ & $\begin{array}{c}0.0791 * * * \\
(0.0261)\end{array}$ & $\begin{array}{l}0.0534 * \\
(0.0281)\end{array}$ \\
\hline LLP_lag & $\begin{array}{c}4.0660 \\
(3.7025)\end{array}$ & $\begin{array}{c}2.9741 \\
(3.5479)\end{array}$ & $\begin{array}{c}2.7212 \\
(3.5805)\end{array}$ & $\begin{array}{c}3.1568 \\
(3.5825)\end{array}$ & $\begin{array}{c}1.3108 \\
(3.7646)\end{array}$ & $\begin{array}{l}-0.5598 \\
(3.4880)\end{array}$ \\
\hline LOSS & $\begin{array}{c}1.4226^{* * *} \\
(0.0497)\end{array}$ & $\begin{array}{c}1.4081 * * * \\
(0.0499)\end{array}$ & $\begin{array}{c}1.4222 * * * \\
(0.0491)\end{array}$ & $\begin{array}{c}1.4192 * * * \\
(0.0490)\end{array}$ & $\begin{array}{c}1.3892 * * * \\
(0.0500)\end{array}$ & $\begin{array}{c}1.4188^{* * *} \\
(0.0479)\end{array}$ \\
\hline CAP & $\begin{array}{c}2.1018 * * * \\
(0.4914)\end{array}$ & $\begin{array}{c}1.9032 * * * \\
(0.4884)\end{array}$ & $\begin{array}{c}1.9942 * * * \\
(0.4940)\end{array}$ & $\begin{array}{c}1.9287 * * * \\
(0.4874)\end{array}$ & $\begin{array}{c}1.8303 * * * \\
(0.4907)\end{array}$ & $\begin{array}{c}1.6243 * * * \\
(0.5144)\end{array}$ \\
\hline year-quarter fixed effects & yes & yes & yes & yes & yes & yes \\
\hline BHC fixed effects & yes & yes & yes & yes & yes & yes \\
\hline $\mathrm{N}$ & 27137 & 27137 & 27137 & 27137 & 27137 & 27137 \\
\hline $\mathrm{R}-\mathrm{sq}$ & 0.3079 & 0.3121 & 0.3110 & 0.3128 & 0.3123 & 0.3162 \\
\hline
\end{tabular}


Table 4. Determinants of the Banking Deregulations - Validity Test

This table presents OLS regressions of bank regulatory reforms on lagged values of discretionary loan loss provisions and other potential predictors of regulatory reforms. Panel A presents five regressions, where the dependent variables are as follows. INTER is a dummy variable equal to one if a BHC is headquartered in a state that has passed an interstate bank deregulation, and zero otherwise. Ln (\# of States) is the natural logarithm of one plus the number of states whose BHCs can enter into the home state in period $t$. Ln (\# of States-Distance Weighted) is the natural logarithm of one plus the number of other states whose can enter the home state in period t, where each of those other states is weighted by the inverse of its distance to the home state. $L n$ (\# of BHCs from Other States) is the natural logarithm of one plus the number of BHCs from other states that can enter the home state in period $t$. In the first two columns of Panel $\mathrm{B}$, the dependent variable is INTRA, which is a dummy variable that equals one if a BHC is headquartered in a state that has removed restrictions on intrastate branching through mergers and acquisitions, and zero otherwise. In columns 3 and 4 of Panel B, the dependent variable is INTER-BRANCH, which is a dummy variable that equals one if the BHC is headquartered in a state that has liberalized restrictions on BHCs in others from establishing bank branches. Since the sample consists of state-year observations from 1986 to 2006 and these analyses assess whether discretionary loan loss provisions predict future deregulations, this table only includes states that deregulated after1986: 22 states started interstate bank deregulation, 20 states deregulated intrastate branching, and all states completed interstate branch deregulation after 1986. The variable state weighted residuals is calculated by the natural logarithm of the absolute value of residuals predicted from equation (1), aggregated to the state level and weighted by the proportion of the BHC's total assets held by its subsidiaries and branches in that state. Following Kroszner and Strahan (1999), the following controls variables are included: GSP per capita, state level unemployment rate, small bank share of all banking assets, and capital ratio of small banks relative to large ones, relative size of insurance in states where banks may sell insurance (zero otherwise), relative size of insurance in states where banks may not sell insurance (zero otherwise), an indicator variable that equal to one if banks may sell insurance (zero otherwise), small firm (fewer than 20 employees) share of the number of firms in the state, unit banking law, share of state government controlled by Democrats, and an indicator that takes a value of one if the state is controlled by one party. We also include state dummy variables. Standard errors are adjusted for state-level clustering and appear in parentheses. $* * *$, and $* * *$ indicate significant at $1 \%, 5 \%$, and $10 \%$.

Panel A. Determinants of Interstate Deregulation

\begin{tabular}{|c|c|c|c|c|c|}
\hline & $(1)$ & $(2)$ & (3) & (4) & $(5)$ \\
\hline Dep Var & \multicolumn{2}{|c|}{ INTER } & Ln(\# of States) & $\begin{array}{c}\text { Ln(\# of States - } \\
\text { Distance Weighted })\end{array}$ & $\begin{array}{c}\text { Ln(\# of BHCs } \\
\text { from Other } \\
\text { States) }\end{array}$ \\
\hline \multirow[t]{2}{*}{$\begin{array}{l}\text { State Weighted Residuals one year } \\
\text { before interstate deregulation }\end{array}$} & 0.0094 & 0.0105 & 0.0820 & 0.0734 & 0.0955 \\
\hline & $(0.0081)$ & $(0.0104)$ & $(0.0580)$ & $(0.0507)$ & $(0.0675)$ \\
\hline \multirow[t]{2}{*}{$\begin{array}{l}\text { State Weighted Residuals two years } \\
\text { before interstate deregulation }\end{array}$} & & 0.0022 & 0.0976 & 0.0848 & 0.1163 \\
\hline & & $(0.0077)$ & $(0.0773)$ & $(0.0658)$ & $(0.0914)$ \\
\hline \multirow[t]{2}{*}{$\begin{array}{l}\text { State Weighted Residuals three } \\
\text { years before interstate deregulation }\end{array}$} & & 0.0020 & 0.0365 & 0.0346 & 0.0423 \\
\hline & & $(0.0072)$ & $(0.0256)$ & $(0.0235)$ & $(0.0298)$ \\
\hline Controls & Yes & Yes & Yes & Yes & Yes \\
\hline N. of observations & 310 & 275 & 275 & 275 & 275 \\
\hline
\end{tabular}


Panel B. Determinants of Intrastate Deregulation and Branching

\begin{tabular}{|c|c|c|c|c|c|}
\hline \multirow{3}{*}{$\begin{array}{l}\text { Dep Var } \\
\text { State Weighted Residuals } \\
\text { one year before Intrastate } \\
\text { deregulation }\end{array}$} & \multirow{2}{*}{\multicolumn{2}{|c|}{ INTRA }} & \multirow{3}{*}{$\begin{array}{l}\text { Dep Var } \\
\text { State Weighted Residuals } \\
\text { one year before Branching } \\
\text { deregulation }\end{array}$} & (3) & (4) \\
\hline & & & & \multicolumn{2}{|c|}{ INTER-BRANCH } \\
\hline & $(0.0118)$ & $(0.0097)$ & & $\begin{array}{l}-0.0049 \\
(0.0087)\end{array}$ & $(0.0094)$ \\
\hline $\begin{array}{l}\text { State Weighted Residuals } \\
\text { two years before Intrastate } \\
\text { deregulation }\end{array}$ & & $(0.0048)$ & $\begin{array}{l}\text { State Weighted Residuals } \\
\text { two years before } \\
\text { Branching deregulation }\end{array}$ & & $(0.0109)$ \\
\hline $\begin{array}{l}\text { State Weighted Residuals } \\
\text { three years before Intrastate } \\
\text { deregulation }\end{array}$ & & $(0.0055)$ & $\begin{array}{l}\text { State Weighted Residuals } \\
\text { three years before } \\
\text { Branching deregulation }\end{array}$ & & $(0.0075)$ \\
\hline Controls & Yes & Yes & Controls & Yes & Yes \\
\hline N. of observations & 328 & 291 & N. of observations & 773 & 682 \\
\hline
\end{tabular}


Table 5. Discretionary Loan Loss Provisions and Weighted Interstate Bank Deregulation

This table presents results of the effects of interstate bank deregulation on discretionary loan loss provisions, where the interstate bank deregulation measures include information on the regulatory environment facing each subsidiary in a BHC. The sample consists of BHC-quarter observations from the third quarter of 1986 through 2006. The dependent variable, discretionary loan loss provisions, is measured as the natural logarithm of the absolute value of residuals from equation (1): $\quad \quad L L P_{i j t}=\alpha_{0}+\alpha_{1} d N P A_{i, j, t+1}+\alpha_{2} d N P A_{i j t}+\alpha_{3} d N P A_{i, j, t-1}+\alpha_{4} \operatorname{SIZE}_{i, j, t-1}+\alpha_{5} d L O A N_{i j t}+\alpha_{6} \operatorname{CSRET}_{j t}+$ $\alpha_{7} d G S P_{j t}+\alpha_{8} d U N E M P_{j t}+\alpha_{9} S T_{j}+\alpha_{10}\left\{D_{j t}\right\}+\varepsilon_{i j t}$, where $\left\{D_{j t}\right\}$ include one (columns 1-3) or two of the deregulation measures (columns 4-9) (INTER, Ln (\# of States), BHC_DIS, BHC_DIS_NUM, BHC_DIS_GDP) corresponding to the deregulation measures used in columns 1-9 of this table. $B H C \_D I S$ is computed as follows: For each BHC in each period, weight its assets across all subsidiaries by the regulatory environment facing each subsidiary (including the subsidiaries in the state of the BHC's headquarters). To calculate the regulatory environment facing each subsidiary in each year, we measure the distance from each subsidiary bank to the capital of every other state, and for each subsidiary in a state $k(k=$ $j$ if headquarter state), weight the interstate deregulation between state $k$ and every other state in period $t$ by that subsidiary's distance to the other state. We use BHC_DIS to represent this bank-specific regulatory environment index. We further weight this regulatory environment index by (a) the number of BHCs in the other state (BHC_DIS_NUM) or (b) the economic size (GSP per capita in \$10,000) of the other state (BHC_DIS_GSP). We take the natural logarithm of the sum of the weighted distance measures. Table 1 defines all the other regressors. Standard errors are heteroskedasticity-consistent, clustered at the state-quarter level, and reported in parentheses. ${ }^{*}, * *$, and $* * *$ indicate significant at $10 \%, 5 \%$, and $1 \%$, respectively.

\begin{tabular}{|c|c|c|c|c|c|c|c|c|c|}
\hline & (1) & $(2)$ & (3) & (4) & $(5)$ & (6) & (7) & $(8)$ & $(9)$ \\
\hline INTER & & & & $\begin{array}{c}-0.5634 * * * \\
(0.0914)\end{array}$ & $\begin{array}{c}-0.5386 * * * \\
(0.0956)\end{array}$ & $\begin{array}{c}-0.5800 * * * \\
(0.0921)\end{array}$ & & & \\
\hline $\operatorname{Ln}(\#$ of States) & & & & & & & $\begin{array}{c}-0.1473 * * * \\
(0.0138)\end{array}$ & $\begin{array}{c}-0.1383 * * * \\
(0.0136)\end{array}$ & $\begin{array}{c}-0.1466^{* * *} \\
(0.0140)\end{array}$ \\
\hline BHC_DIS & $\begin{array}{c}-0.0312 * * * \\
(0.0084)\end{array}$ & & & $\begin{array}{c}-0.0449 * * * \\
(0.0087)\end{array}$ & & & $\begin{array}{c}-0.0444 * * * \\
(0.0089)\end{array}$ & & \\
\hline BHC_DIS_NUM & & $\begin{array}{c}-0.0262 * * * \\
(0.0065)\end{array}$ & & & $\begin{array}{c}-0.0353 * * * \\
(0.0070)\end{array}$ & & & $\begin{array}{c}-0.0308 * * * \\
(0.0073)\end{array}$ & \\
\hline BHC_DIS_GSP & & & $\begin{array}{c}-0.0333 * * * \\
(0.0070)\end{array}$ & & & $\begin{array}{c}-0.0454 * * * \\
(0.0079)\end{array}$ & & & $\begin{array}{c}-0.0440 * * * \\
(0.0081)\end{array}$ \\
\hline $\operatorname{logSIZE}$ & $\begin{array}{c}0.0351 \\
(0.0268)\end{array}$ & $\begin{array}{c}0.0317 \\
(0.0266)\end{array}$ & $\begin{array}{c}0.0343 \\
(0.0261)\end{array}$ & $\begin{array}{c}0.0264 \\
(0.0265)\end{array}$ & $\begin{array}{c}0.0258 \\
(0.0267)\end{array}$ & $\begin{array}{c}0.0269 \\
(0.0266)\end{array}$ & $\begin{array}{c}0.0034 \\
(0.0282)\end{array}$ & $\begin{array}{c}0.0157 \\
(0.0279)\end{array}$ & $\begin{array}{c}0.0087 \\
(0.0279)\end{array}$ \\
\hline LLP_lag & $\begin{array}{c}2.9553 \\
(3.6252)\end{array}$ & $\begin{array}{c}3.1087 \\
(3.6067)\end{array}$ & $\begin{array}{c}2.2895 \\
(3.6908)\end{array}$ & $\begin{array}{c}2.9514 \\
(3.6532)\end{array}$ & $\begin{array}{c}3.2929 \\
(3.6182)\end{array}$ & $\begin{array}{c}2.8612 \\
(3.6798)\end{array}$ & $\begin{array}{c}0.7583 \\
(3.7628)\end{array}$ & $\begin{array}{c}0.9441 \\
(3.7610)\end{array}$ & $\begin{array}{c}0.4695 \\
(3.7763)\end{array}$ \\
\hline LOSS & $\begin{array}{c}1.3961^{* * *} \\
(0.0510)\end{array}$ & $\begin{array}{c}1.3945 * * * \\
(0.0508)\end{array}$ & $\begin{array}{c}1.3970 * * * \\
(0.0506)\end{array}$ & $\begin{array}{c}1.3910 * * * \\
(0.0503)\end{array}$ & $\begin{array}{c}1.3889 * * * \\
(0.0506)\end{array}$ & $\begin{array}{c}1.3933 * * * \\
(0.0499)\end{array}$ & $\begin{array}{c}1.4107 * * * \\
(0.0485)\end{array}$ & $\begin{array}{c}1.4086^{* * *} \\
(0.0488)\end{array}$ & $\begin{array}{c}1.4043 * * * \\
(0.0490)\end{array}$ \\
\hline CAP & $\begin{array}{c}1.9918^{* * *} \\
(0.5304)\end{array}$ & $\begin{array}{c}2.0471 * * * \\
(0.5342)\end{array}$ & $\begin{array}{c}1.9712 * * * \\
(0.5311)\end{array}$ & $\begin{array}{c}2.0465^{* * *} \\
(0.5254)\end{array}$ & $\begin{array}{c}2.0116^{* * *} \\
(0.5314)\end{array}$ & $\begin{array}{c}1.9299 * * * \\
(0.5364)\end{array}$ & $\begin{array}{c}1.4548 * * * \\
(0.5416)\end{array}$ & $\begin{array}{c}1.5068 * * * \\
(0.5379)\end{array}$ & $\begin{array}{c}1.4274 * * * \\
(0.5347)\end{array}$ \\
\hline year-quarter fixed effects & yes & yes & yes & yes & yes & yes & yes & yes & yes \\
\hline BHC fixed effects & yes & yes & yes & yes & yes & yes & yes & yes & yes \\
\hline $\mathrm{N}$ & 25803 & 25803 & 25803 & 25803 & 25803 & 25803 & 25803 & 25803 & 25803 \\
\hline R-sq & 0.3157 & 0.3167 & 0.3190 & 0.3182 & 0.3145 & 0.3188 & 0.3185 & 0.3181 & 0.3212 \\
\hline
\end{tabular}


Table 6. Financial Restatement After the Banking Deregulation

This table presents regression results of the (dynamic) effects of interstate branching deregulation on the incidence of financial restatements. The sample consists of BHC-year observations from year 1993 through 2006.The dependent variable, the incidence of financial restatement (RESTATEMENT), equals one if the BHC restates its financial restatements in year $\mathrm{t}$ and zero otherwise INTER-BRANCH is defined as a dummy variable takes the value of one if the BHC is headquartered in a state that has the State Interstate Branching Laws takes effective by the beginning of year $t$, and zero otherwise. Columns 1, 3 and 5 use probit regression models, and present estimated marginal effects $(\mathrm{dy} / \mathrm{dx})$. The marginal effect of a dummy variable is calculated as the discrete change in the expected value of the dependent variable from 0 to 1 . Columns 2,4 and 6 use OLS. INTER-BRANCH is a dummy variable that equals one if the $\mathrm{BHC}$ is headquartered in a state that has liberalized restrictions on BHCs in others from establishing bank branches. Columns 3-6 present results of the dynamic effects, where financial restatement is modeled by (leads and) lags (from years before) to five years or more after the interstate branch deregulation. The reference group is the interstate branch deregulation year. Table 1 defines the other regressors. Standard errors are heteroskedasticity-consistent, clustered at the state-year level, and reported in parentheses. $* * *$, and $* * *$ indicate significant at $10 \%, 5 \%$, and $1 \%$, respectively.

\begin{tabular}{lcccccc}
\hline & $(1)$ & $(2)$ & $(3)$ & $(4)$ & $(5)$ & $(6)$ \\
MODEL & Probit & OLS & Probit & OLS & Probit & OLS \\
\hline INTER-BRANCH & $-0.0951^{*}$ & $-0.0571^{*}$ & & & & \\
& $(0.0522)$ & $(0.0329)$ & & & & \\
Years before INTER-BRANCH & & & & & 0.0957 & 0.0508 \\
& & & & & $(0.0705)$ & $(0.0375)$ \\
Year 1 after INTER-BRANCH & & & -0.0758 & -0.0515 & -0.0578 & -0.0389 \\
& & & $(0.0409)$ & $(0.0347)$ & $(0.0463)$ & $(0.0360)$ \\
Year 2 after INTER-BRANCH & & & $-0.1470^{* * *}$ & $-0.1105^{* * *}$ & $-0.1480^{* * *}$ & $-0.1114^{* * *}$ \\
& & & $(0.0323)$ & $(0.0381)$ & $(0.0320)$ & $(0.0379)$ \\
Year 3 after INTER-BRANCH & & & $-0.1570^{* * *}$ & $-0.1200^{* *}$ & $-0.1600^{* * *}$ & $-0.1226^{* *}$ \\
& & & $(0.0418)$ & $(0.0516)$ & $(0.0407)$ & $(0.0512)$ \\
Year 4 after INTER-BRANCH & & & $-0.2070^{* * *}$ & $-0.1772^{* * * *}$ & $-0.2120^{* * *}$ & $-0.1848^{* * *}$ \\
& & & $(0.0312)$ & $(0.0564)$ & $(0.0292)$ & $(0.0559)$ \\
Year 5+ after INTER-BRANCH & & & $-0.2580^{* *}$ & $-0.1603 * *$ & $-0.2790^{* *}$ & $-0.1723^{* * *}$ \\
& & & $(0.0886)$ & $(0.0649)$ & $(0.0866)$ & $(0.0642)$ \\
logSIZE & -0.0014 & 0.0037 & -0.0057 & 0.0029 & -0.0077 & 0.0026 \\
& $(0.0337)$ & $(0.0225)$ & $(0.0333)$ & $(0.0223)$ & $(0.0331)$ & $(0.0222)$ \\
LLP_lag & -1.0560 & 0.1722 & -1.4490 & 0.1557 & -1.1870 & 0.2091 \\
& $(6.4770)$ & $(4.8089)$ & $(6.5690)$ & $(4.8431)$ & $(6.5730)$ & $(4.8433)$ \\
Loss & $0.2900^{* * * *}$ & $0.1328^{* * *}$ & $0.3010^{* *}$ & $0.1339^{* * *}$ & $0.2970^{* *}$ & $0.1337^{* * *}$ \\
& $(0.0960)$ & $(0.0517)$ & $(0.0955)$ & $(0.0516)$ & $(0.0953)$ & $(0.0516)$ \\
CAP & $1.2270^{* *}$ & 0.4452 & $1.2350^{*}$ & 0.4485 & $1.2400^{*}$ & 0.4518 \\
year fixed effects & $(0.5860)$ & $(0.3063)$ & $(0.5860)$ & $(0.3082)$ & $(0.5870)$ & $(0.3080)$ \\
BHC fixed effects & yes & yes & yes & yes & yes & yes \\
R -sq & yes & yes & yes & yes & yes & yes \\
& 2875 & 5520 & 2875 & 5520 & 2875 & 5520 \\
& 0.1587 & 0.3050 & 0.1620 & 0.3065 & 0.1629 & 0.3070 \\
\hline & & & & & &
\end{tabular}


Appendix Table 1. Years of Deregulation By State

\begin{tabular}{|c|c|c|c|}
\hline State & Interstate banking permitted & $\begin{array}{l}\text { Intrastate branching } \\
\text { through M\&A }\end{array}$ & $\begin{array}{c}\text { Interstate Banking and } \\
\text { Branching Efficiency Act }\end{array}$ \\
\hline $\mathrm{AL}$ & 1987 & 1981 & 1997 \\
\hline $\mathrm{AK}$ & 1982 & before 1970 & 1994 \\
\hline $\mathrm{AZ}$ & 1986 & before 1970 & 1996 \\
\hline AR & 1989 & 1994 & 1997 \\
\hline $\mathrm{CA}$ & 1987 & before 1970 & 1995 \\
\hline $\mathrm{CO}$ & 1988 & 1991 & 1997 \\
\hline $\mathrm{CT}$ & 1983 & 1980 & 1995 \\
\hline $\mathrm{DE}$ & 1988 & before 1970 & 1995 \\
\hline DC & 1985 & before 1970 & 1996 \\
\hline FL & 1985 & 1988 & 1997 \\
\hline GA & 1985 & 1983 & 1997 \\
\hline $\mathrm{HI}$ & - & 1986 & 1997 \\
\hline ID & 1985 & before 1970 & 1995 \\
\hline $\mathrm{IL}$ & 1986 & 1988 & 1997 \\
\hline IN & 1986 & 1989 & 1996 \\
\hline IA & 1991 & - & 1996 \\
\hline KS & 1992 & 1987 & 1997 \\
\hline KY & 1984 & 1990 & 1997 \\
\hline LA & 1987 & 1988 & 1997 \\
\hline $\mathrm{ME}$ & 1978 & 1975 & 1997 \\
\hline MD & 1985 & before 1970 & 1995 \\
\hline MA & 1983 & 1984 & 1996 \\
\hline MI & 1986 & 1987 & 1995 \\
\hline MN & 1986 & 1993 & 1997 \\
\hline MS & 1988 & 1986 & 1997 \\
\hline MO & 1986 & 1990 & 1997 \\
\hline MT & 1993 & 1990 & 1997 \\
\hline $\mathrm{NE}$ & 1990 & 1985 & 1997 \\
\hline NV & 1985 & before 1970 & 1995 \\
\hline $\mathrm{NH}$ & 1987 & 1987 & 1997 \\
\hline NJ & 1986 & 1977 & 1996 \\
\hline NM & 1989 & 1991 & 1996 \\
\hline NY & 1982 & 1976 & 1996 \\
\hline $\mathrm{NC}$ & 1985 & before 1970 & 1995 \\
\hline ND & 1991 & 1987 & 1997 \\
\hline $\mathrm{OH}$ & 1985 & 1979 & 1997 \\
\hline OK & 1987 & 1988 & 1997 \\
\hline OR & 1986 & 1985 & 1995 \\
\hline PA & 1986 & 1982 & 1995 \\
\hline RI & 1984 & before 1970 & 1995 \\
\hline $\mathrm{SC}$ & 1986 & before 1970 & 1996 \\
\hline SD & 1988 & before 1970 & 1996 \\
\hline $\mathrm{TN}$ & 1985 & 1985 & 1997 \\
\hline $\mathrm{TX}$ & 1987 & 1988 & 1995 \\
\hline UT & 1984 & 1981 & 1995 \\
\hline VT & 1988 & 1970 & 1996 \\
\hline
\end{tabular}




\begin{tabular}{cccc} 
VA & 1985 & 1978 & 1995 \\
WA & 1987 & 1985 & 1996 \\
WV & 1988 & 1987 & 1997 \\
WI & 1987 & 1990 & 1997 \\
WY & 1987 & 1988 & 1997 \\
\hline
\end{tabular}




\section{Appendix Table 2. Discretionary Loan Loss Provisions and Deregulation}

This table presents results of the effects of banking deregulations on discretionary loan loss provisions. The sample consists of BHC-quarter observations from the third quarter of 1986 through 2006. The dependent variable, discretionary loan loss provisions, is measured as the natural logarithm of the absolute value of residuals from equation (1A): $L L P_{i j t}=\alpha_{0}+\alpha_{1} d N P A_{i, j, t+1}+\alpha_{2} d N P A_{i j t}+\alpha_{3} d N P A_{i, j, t-1}+\alpha_{4} \operatorname{SIZE}_{i, j, t-1}+\alpha_{5} d L O A N_{i j t}+\alpha_{6} \operatorname{CSRET}_{j t}+$ $\alpha_{7} d G S P_{j t}+\alpha_{8} d U N E M P_{j t}+\alpha_{9} S T_{j}+\varepsilon_{i j t}$. INTER is a dummy variable equal to one if a BHC is headquartered in a state that has passed an interstate bank deregulation, and zero otherwise. Ln (\# of States) is the natural logarithm of one plus the number of states whose BHCs can enter into the home state in period $t$. Ln (\# of States-Distance Weighted) is the natural logarithm of one plus the number of other states whose can enter the home state in period $\mathrm{t}$, where each of those other states is weighted by the inverse of its distance to the home state. Ln (\# of BHCs from Other States) is the natural logarithm of one plus the number of BHCs from other states that can enter the home state in period $t$. INTRA is a dummy variable that equals one if a $\mathrm{BHC}$ is headquartered in a state that has removed restrictions on intrastate branching through mergers and acquisitions, and zero otherwise. INTER-BRANCH is a dummy variable that equals one if the BHC is headquartered in a state that has liberalized restrictions on BHCs in others from establishing bank branches. Table 1 defines the other regressors. Standard errors are heteroskedasticity-consistent, clustered at the state-quarter level, and reported in parentheses. $*, * *$, and $* * *$ indicate significant at $10 \%, 5 \%$, and $1 \%$, respectively.

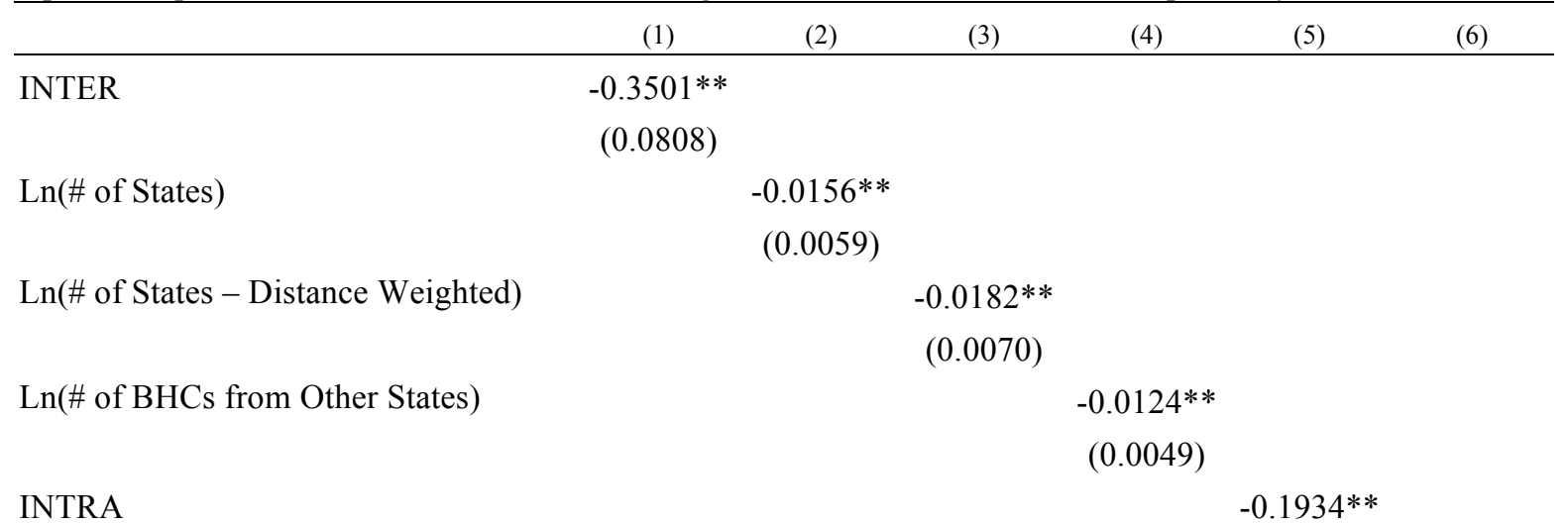

INTRA

$(0.0590)$

INTER-BRANCH

$-0.1002 * *$

\begin{tabular}{lccccccc} 
& & & $0.0475)$ \\
logSIZE & $0.0783 * * *$ & $0.0825 * * *$ & $0.0826 * * *$ & $0.0826 * * *$ & $0.0860 * * *$ & $0.0858 * * *$ \\
& $(0.0267)$ & $(0.0270)$ & $(0.0270)$ & $(0.0270)$ & $(0.0268)$ & $(0.0270)$ \\
LLP_lag & 4.2658 & 4.5301 & 4.5371 & 4.5299 & 4.1766 & 4.3823 \\
& $(3.6782)$ & $(3.6955)$ & $(3.6964)$ & $(3.6993)$ & $(3.6847)$ & $(3.6977)$ \\
LOSS & $1.4138 * * *$ & $1.4181 * * *$ & $1.4183 * * *$ & $1.4183 * * *$ & $1.4130 * * *$ & $1.4164 * * *$ \\
& $(0.0504)$ & $(0.0504)$ & $(0.0504)$ & $(0.0504)$ & $(0.0505)$ & $(0.0504)$ \\
CAP & $1.7071 * * *$ & $1.6894 * * *$ & $1.6885 * * *$ & $1.6925 * * *$ & $1.6965 * * *$ & $1.6634 * * *$ \\
& $(0.4878)$ & $(0.4866)$ & $(0.4866)$ & $(0.4866)$ & $(0.4878)$ & $(0.4876)$ \\
year-quarter fixed effects & yes & yes & yes & yes & yes & yes \\
BHC fixed effects & yes & yes & yes & yes & yes & yes \\
N & 27137 & 27137 & 27137 & 27137 & 27137 & 27137 \\
R-sq & 0.3104 & 0.3098 & 0.3098 & 0.3098 & 0.3099 & 0.3097 \\
\hline
\end{tabular}




\section{Appendix Table 3. Robustness Checks - Using Alternative Discretionary Provision Measures}

This table presents results of the effects of banking deregulations on alternative measures of discretionary loan loss provisions. The sample consists of BHC-quarter observations from the third quarter of 1986 through 2006. The dependent variable, discretionary loan loss provisions, is measured as the natural logarithm of the absolute value of residuals predicted from each of the following models.

Column 1: Model (a) in Beatty and Liao's (2014) Survey paper.

$$
\begin{gathered}
L L P_{i j t}=\alpha_{0}+\alpha_{1} d N P A_{i, j, t+1}+\alpha_{2} d N P A_{i j t}+\alpha_{3} d N P A_{i, j, t-1}+\alpha_{4} d N P A_{i, j, t-2}+\alpha_{5} S I Z E_{i, j, t-1}+\alpha_{6} d L O A N_{i j t} \\
+\alpha_{7} \operatorname{CSRET}_{j t}+\alpha_{8} d G S P_{j t}+\alpha_{9} d U N E M P_{j t}+\alpha_{10}\left\{D_{j t}\right\}+\varepsilon_{i j t}
\end{gathered}
$$

Column 2: Model (b) in Beatty and Liao's (2014) Survey paper.

$$
\begin{gathered}
L L P_{i j t}=\alpha_{0}+\alpha_{1} d N P A_{i, j, t+1}+\alpha_{2} d N P A_{i j t}+\alpha_{3} d N P A_{i, j, t-1}+\alpha_{4} d N P A_{i, j, t-2}+\alpha_{5} S I Z E_{i, j, t-1}+\alpha_{6} d L O A N_{i j t} \\
+\alpha_{7} \operatorname{CSRET}_{j t}+\alpha_{8} d G S P_{j t}+\alpha_{9} d U N E M P_{j t}+\alpha_{10} A L W_{i, j, t-1}+\alpha_{11}\left\{D_{j t}\right\}+\varepsilon_{i j t}
\end{gathered}
$$

Column 3: Model in Kanagaretnam et al. (2010) or Model (3) in Beatty and Liao's (2014) Survey paper (with macro controls).

$$
\begin{gathered}
L L P_{i j t}=\alpha_{0}+\alpha_{1} A L W_{i, j, t-1}+\alpha_{2} N P A_{i, j, t-1}+\alpha_{3} C_{i j t}+\alpha_{4} d L O A N_{i j t}+\alpha_{5} L O A N_{i j t}+\alpha_{6} \operatorname{CSRET}_{j t}+\alpha_{7} d G S P_{j t} \\
+\alpha_{8} d U N E M P_{j t}+\alpha_{9}\left\{D_{j t}\right\}+\varepsilon_{i j t}
\end{gathered}
$$

Column 4: Model in Bushman and Williams (2012) or Model (9) in Beatty and Liao's (2014) Survey paper.

$$
\begin{gathered}
L L P_{i j t}=\alpha_{0}+\alpha_{1} d N P A_{i, j, t+1}+\alpha_{2} d N P A_{i j t}+\alpha_{3} d N P A_{i, j, t-1}+\alpha_{4} d N P A_{i, j, t-2}+\alpha_{5} S I Z E_{i, j, t-1}+\alpha_{6} d G S P_{j t} \\
+\alpha_{7}\left\{D_{j t}\right\}+\varepsilon_{i j t}
\end{gathered}
$$

\begin{tabular}{|c|c|c|c|c|c|c|c|c|}
\hline & (1) & (2) & (3) & (4) & (5) & (6) & (7) & (8) \\
\hline INTER & $\begin{array}{c}-0.2716^{* * *} \\
(0.0945)\end{array}$ & $\begin{array}{c}-0.2381 * * \\
(0.0946)\end{array}$ & $\begin{array}{c}-0.2013 * * \\
(0.0802)\end{array}$ & $\begin{array}{c}-0.3613 * * * \\
(0.0914)\end{array}$ & & & & \\
\hline $\operatorname{Ln}(\#$ of States) & & & & & $\begin{array}{c}-0.0369 * * * \\
(0.0057)\end{array}$ & $\begin{array}{c}-0.0380 * * * \\
(0.0063)\end{array}$ & $\begin{array}{c}-0.0131 * * \\
(0.0063)\end{array}$ & $\begin{array}{c}-0.0516 * * * \\
(0.0065)\end{array}$ \\
\hline $\log \mathrm{SIZE}$ & $\begin{array}{c}0.0059 \\
(0.0283)\end{array}$ & $\begin{array}{c}-0.0963 * * * \\
(0.0288)\end{array}$ & $\begin{array}{c}-0.0824 * * * \\
(0.0302)\end{array}$ & $\begin{array}{c}0.0097 \\
(0.0273)\end{array}$ & $\begin{array}{c}0.0388 \\
(0.0278)\end{array}$ & $\begin{array}{c}-0.0796 * * * \\
(0.0304)\end{array}$ & $\begin{array}{c}-0.0626^{* *} \\
(0.0310)\end{array}$ & $\begin{array}{l}0.0496^{*} \\
(0.0273)\end{array}$ \\
\hline LLP_lag & $\begin{array}{c}8.8296 * * * \\
(3.3945)\end{array}$ & $\begin{array}{c}12.4364 * * * \\
(3.3166)\end{array}$ & $\begin{array}{c}13.7289 * * * \\
(3.8039)\end{array}$ & $\begin{array}{l}6.0870 * \\
(3.5686)\end{array}$ & $\begin{array}{c}8.5438 * * * \\
(3.2912)\end{array}$ & $\begin{array}{c}12.1089 * * * \\
(3.2177)\end{array}$ & $\begin{array}{c}13.7652 * * * \\
(3.8846)\end{array}$ & $\begin{array}{l}7.4417 * * \\
(3.4411)\end{array}$ \\
\hline LOSS & $\begin{array}{c}1.3671 * * * \\
(0.0497)\end{array}$ & $\begin{array}{c}1.3539 * * * \\
(0.0517)\end{array}$ & $\begin{array}{c}0.9397 * * * \\
(0.0485)\end{array}$ & $\begin{array}{c}1.4092 * * * \\
(0.0507)\end{array}$ & $\begin{array}{c}1.3692 * * * \\
(0.0494)\end{array}$ & $\begin{array}{c}1.3656^{* * *} \\
(0.0499)\end{array}$ & $\begin{array}{c}0.9419 * * * \\
(0.0485)\end{array}$ & $\begin{array}{c}1.3966 * * * \\
(0.0503)\end{array}$ \\
\hline CAP & $\begin{array}{l}1.3294 * * \\
(0.5314)\end{array}$ & $\begin{array}{c}1.7347 * * * \\
(0.5338)\end{array}$ & $\begin{array}{c}0.5949 \\
(0.5268)\end{array}$ & $\begin{array}{l}0.9634^{*} \\
(0.5055)\end{array}$ & $\begin{array}{c}1.5825^{* * *} \\
(0.5186)\end{array}$ & $\begin{array}{c}1.7816^{* * *} \\
(0.5544)\end{array}$ & $\begin{array}{c}0.6087 \\
(0.5358)\end{array}$ & $\begin{array}{c}1.4684 * * * \\
(0.5102)\end{array}$ \\
\hline year-quarter fixed effects & yes & yes & yes & yes & yes & yes & yes & yes \\
\hline BHC fixed effects & yes & yes & yes & yes & yes & yes & yes & yes \\
\hline N. of observations & 26149 & 26149 & 26149 & 26149 & 26149 & 26149 & 26149 & 26149 \\
\hline R-sq & 0.3027 & 0.3024 & 0.3189 & 0.2914 & 0.3051 & 0.2978 & 0.3173 & 0.2905 \\
\hline
\end{tabular}

All of these models also include state fixed effects in predicting abnormal LLPs. Here $\left\{D_{j t}\right\}$ represents one of the two deregulation measures (INTER or Ln (\# of States) corresponding to each of the deregulation measures used in columns 1-8 of this table. INTER is a dummy variable equal to one if a BHC is headquartered in a state that has passed an interstate bank deregulation, and zero otherwise. Ln (\# of States) is the natural logarithm of one plus the number of states whose BHCs can enter into the home state in period $t$. Table 1 defines the other regressors. Standard errors are heteroskedasticity-consistent, clustered at the state-quarter level, and reported in parentheses. $*, * *$, and $* * *$ indicate significant at $10 \%, 5 \%$, and $1 \%$, respectively. 